$\therefore$ Y3.At $7: 22 / R M E-33$

nge

UNIVERSITY OF

APR 281954

Nin.

UNITED STATES ATOMIC ENERGY COMMISSION

RME-33

URANIUM ORE CONTROLS OF THE HAPPY JACK DEPOSIT, WHITE CANYON, SAN JUAN COUNTY, UTAH

By

Leo J. Miller

March 26, 1953

Grand Junction Operations Office

Exploration Division

Grand Junction, Colorado

IIETCY

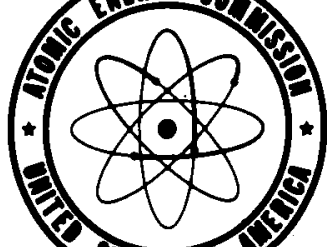

याres as

Technical Information Service, Oak Ridoe, Tennessee 
Subject Category, GEOLOGY AND MINERALOGY.

This report has been reproduced with minimum alteration directly from manuscript provided the Technical Information Service in an effort to expedite availability of the information contained herein.

The United States Atomic Energy Commission makes no representation or warranty as to the accuracy or completeness of the information herein and makes no recommendation concerning it.

Reproduction of this information is encouraged by the United States Atomic Energy Commission. Arrangements for your republication of this document in whole or in part should be made with the author and the organization he represents. 
URANIUM ORE CONTROIS OF THE HAPPY JACK DEPOSIT

WHITE CANYON, SAH JUAN COUNTY

OTAE

COATERTS

Mbtract. . . . . . . . . . . . . page 5

Introduction. .................. 5

Provlous rork ................... 9

Doology ................... 9

Channel structure. .......... ... 9

Channel sodinonts. . . . . . . . . .. 9 9

loglonal diatribution of Shinarump conglomerate. 12

Coomorphology and climatio change. . . . . . I4

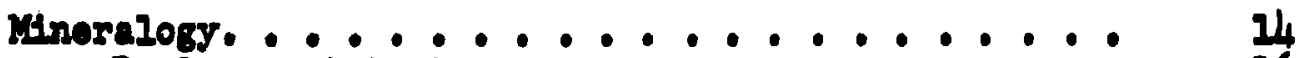

Replacement toxtures ............. 16

Organio mattor ............... 16

Chaloopyrite after pyrite. . . ...... 17

Replacement of quartz and microcline . . . . 17

Replacement of clay cement ......... 17

Irregular border of uraninite and the .

copper sulfides. ........... 17

Replacement in fractures.......... 17

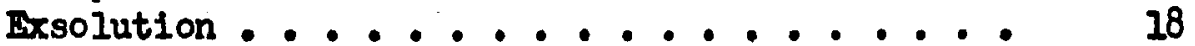

Time relationship between minerals...... 18

Alteration ............... 18

Intra-channel ore controls. ......... 19

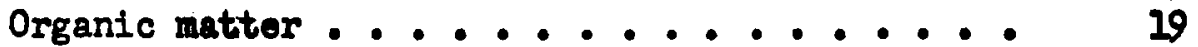

Iithologic controls. ............ 19

Bedding planes . . . . . . . . . . . 19

Channel lows . . . . . . . . . . . . 20

Fractures................. 24

Conclusions . . . . . . . . . . . . 24

References ................ . 25

$-3-$ 


\section{ILLUSTRATIOWS}

Fige

Page

1. Location map of Happy Jack mine. ......... 6

2. Generallzed section of the Heppy Jack area .... 7

3. Tectonic map of southeastern Otah. . . . . . . 8

4. Cross section of Sunrise ohannel ......... 10

5. Channel otmucture contour map of Happy Jack mine - 11

6. Regional distribution of the Shinarump conglomerate 13

7. Cross sections AA'-GG' of Happy Jack mino. . . . 20

8. Cross section HH'-W' of Happy Jack mine..... 21

9. Fence diagram Happy Jack mine. ......... 23

10. Lower Shinarump mudstone map, Happy Jack mine... 24

Plate

I-A Filling of wood cells by chaloopyrite. . . . . 27

I-B Flliling of wood cells by bornite......... 27

II-A Cryotalifine halos of chalcocite, pyrite, and chalcopyrite within a wood coll. ....... 28

II-B Pruedomorph of chalcopyrite after pysite..... 28

III-1 Replacenent of quartz by uraninite........ 29

III-B Replacenent of microcline along clearage planes by chaloopyrite and uranint te. . . . . . 29

IV $x$ Intergrowth of uranintte and ohalcopysite. . . 30

IV-B Uraninite orose outting chaloopssite and bornite - 30

V-A Repleoument of a fracture in quarts by ohaloopyrits 31

V-B Replacemont of a eraoture in iledetone by ohal-

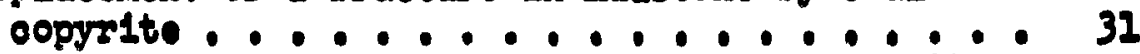

VI-A Replacement of quarts overgrowth by chaloopyrite

and urantnite. ............... 32 Roplacument of madetone by ohaloopyrite and uraninito................... 32

VI-l Roplaoonont of a iraoture in ohaloopyrite by

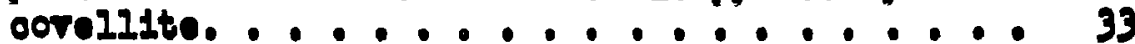

VI-B Bxoolution texture of oheloopyrite and borntto . . 33

VII-A Broohantite within fraotires in quarts ...... 34

VIII-B Band of uraninite mixed with oopper oulfidos l-foot thiok along a bodding plane ...... 34 


\title{
URANIUM ORE CONTROLS OF THE HAPPY JACK DEPOSTT \\ WHITE CANYON, SAN JUAN COUNTY
}

UTAH

\begin{abstract}
The Heppy Jack uranium deposit of White Canyon, San Juan County, Utah, was studied in connection with an Atomic Inergy Comission exploration program. The major urantum ore control is a paleostream channel containing sediments of the Shinamump conglomerate. Intrachannel controls include organic matter, lithologic variations, and channel "lowg".

Kicroscopic studies reveal that uraninite, the primary ore minoral, occurs as cement and as a replacement of organic material. Both the uraninite and copper sulfides replace secondary quartz overgrowths. Cryotilo of chalcopyrite, chalcocite, and pyrite occur one within the other. Brsolution of borntte and chalcopyrite is present. Oraninite 1s dated as later than the secondary overgrowths and of about the same age as the copper sulfides.
\end{abstract}

\section{INTRODUCIIOR}

Study of the Bappy Jack uranium depostt was undertaken during Aptil and My 1952, as proltminary work for a dianond drillting program carried out by the $J$. S. Atomio sners commiselon. The ore controlo desoribed herein were tentatively outined by this otudy and heve beon largely confirmed by the drilling. The reglonal ploture of the shina. rump conglomerate has boen developed by the author and collengues as part of a oontinuing study of the White Cenyon urantum deposits oarried

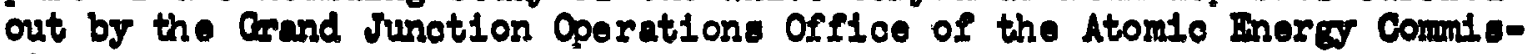
aton.

The Heps Jaok mine 10 located in the White Canyon of San Juen Oounty, southoastern Utah, adjeoent to Utah Stato HIghway 95 (fIg. 1). Ixposed formatione, all of whioh aro continental doposits, rango in age from Pormian through Jurasalo $(11 \mathrm{~g}, 2)$, The topography is rugged with the oreste of the oanyon walle 2,500 feot above the valley noor.

White Oanyon is on the west flenk of the Monument upwarp, a brond struotural feature looally known as the Jlk Ridge antioline (f1g. 3). The bedi have a uniform otrike of $\mathrm{N} .15^{\circ} \mathrm{W}$. and dip $13^{\circ} \mathrm{sW}$. A oonjugate joint gyotom is manifeat throughout the ares with the dominant oot otriking N. $50^{\circ} \mathrm{K}$, and the minor got N. $55^{\circ}$ W. Both sota have a vortloal dip. 


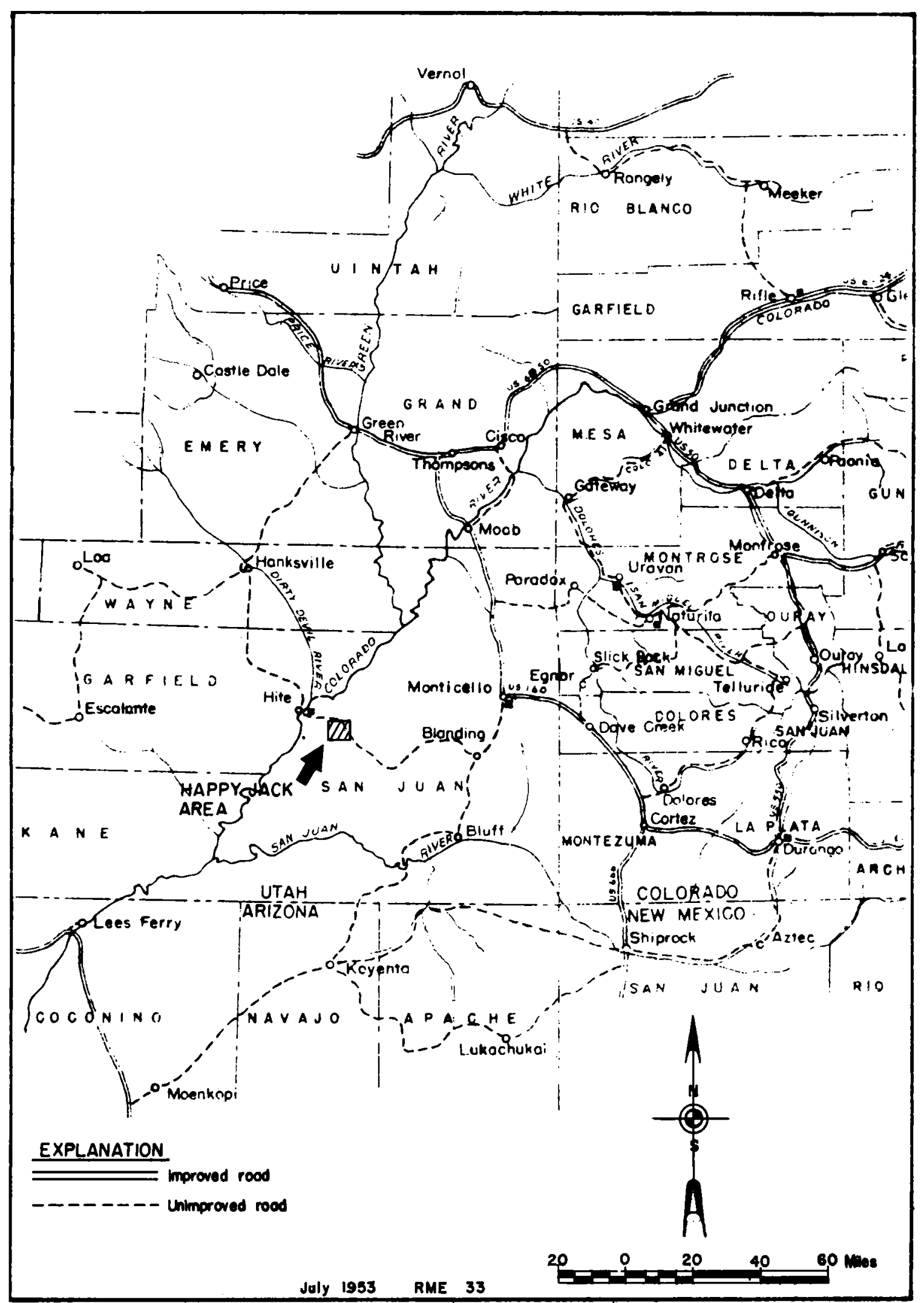

Figure I. Location mep of Happy Jack mine, San Juan County, Utah 


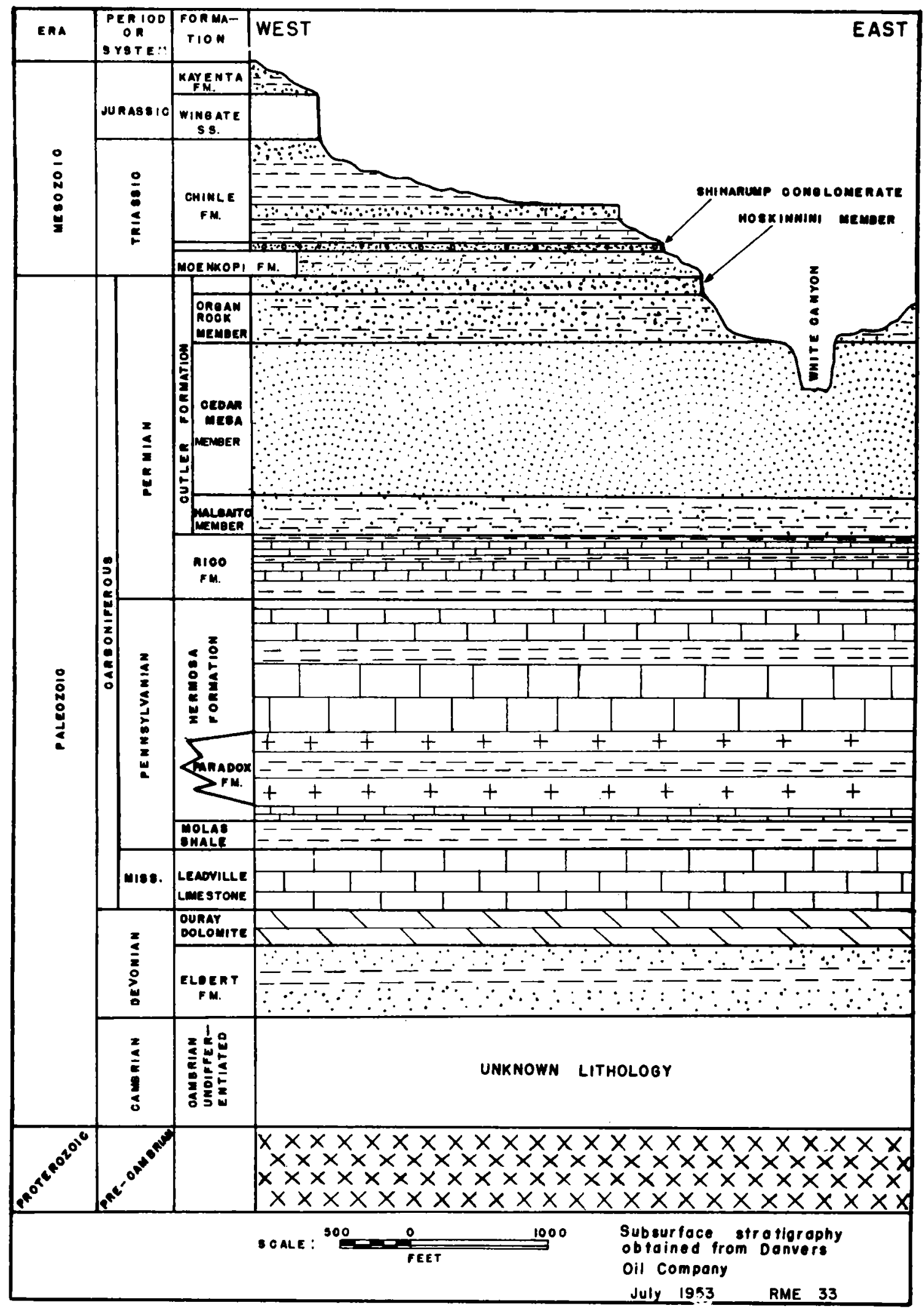

Figure 2. Generalized section of the Hoppy Jack area, San Juan County, Utah 


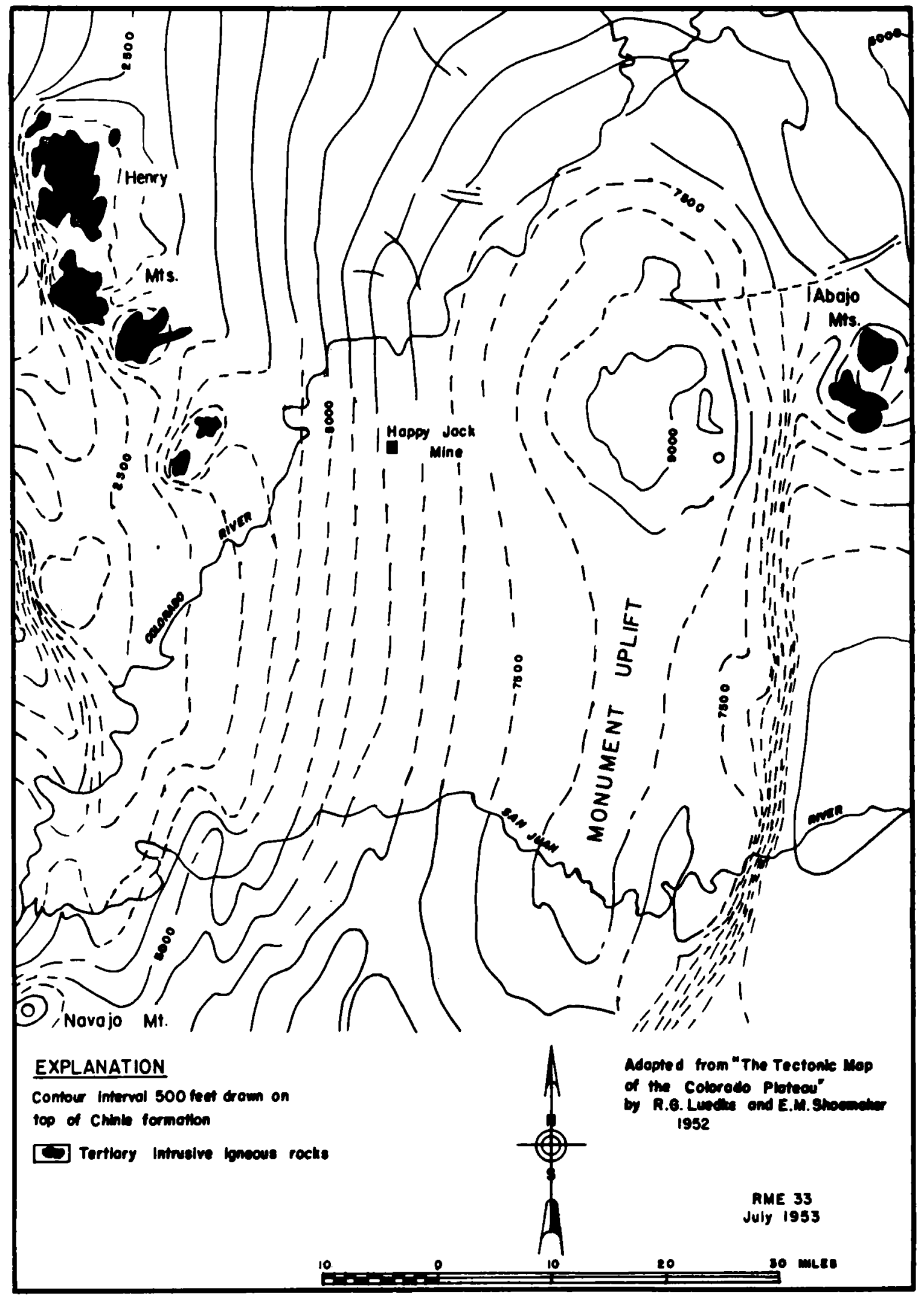

Figire 3. Tectonic map of Southeostern Utah 
Gregory (1938) carried out the earliest reconnaissance of the region. I Fischer and King (1948), 2/ Smyth (1949), 3/ Granger and Beroni (1950), 4/ and Benson, et al (1952), 5/ have investigated the area and Dodd (1950), 6/ mapped a portion of the Happy Jack mine. Bain (195I) has also recorded his impression of the Happy Jack: I/ Gruner and Gardiner (1952) have written a brief account of the mineralization. 8/

\section{GEOLOGY}

The Happy Jack has been the most productive among a number of uranium-copper_deposits in the White Canyon area. AlI are in the Triassic Shinarump conglomerate. This formation is a lenticular sandstone fluvial in origin, conformable with the Chinle formation above, and disconformable with the Moenkopi formation below.

A distinctive feature of the Shinarump - one related to ore deposition - is the relation of its thickness to the configuration of the irregular erosion surface on which it was deposited. ,This surface, the top of the Moenkopi formation, is marked by paleodrainage channels which are filled by Shinarump clastics. These sediments extend beyond the narrow confines of the channel and wedge-out in certain inter-channel areas.

\section{Channel Structure}

Each Shinarump sandstone lens has filled one to three channels. In cross section a typical channel is an asymmetrical trough, incised into the Moenkopi formation. It is 100 to 250 feet wide and 20 to 40 feet deep (fig. 4). Along its course the undulating basal surface of a Shinarump channel may have a relief as high as 40 feet (fig. 5 ). As a rule the channel maintains a relatively straight course; however, the Happy Jack channel is an exception for it changes direction abruptly in the eastern portion of the area.

\section{Channel Sediments}

On the basis of lithology, the Shinarump channel sediments may be subdivided into three sedimentary units (fig. 4).

Unit 3 (upper unit) Sandstone, white, weathers to buff: Thickness, feet quartzose, coarse-grained, poorly sorted, friable; grains sub-angular, clay cement, contains microcline fragments up to an inch in diameter; crosslaminated, caps the channels and occupies the intervening area; cliff-forming- - . - . - - 28 This unit is not usually ore-bearing, except locally in the Happy Jack mine. 
A

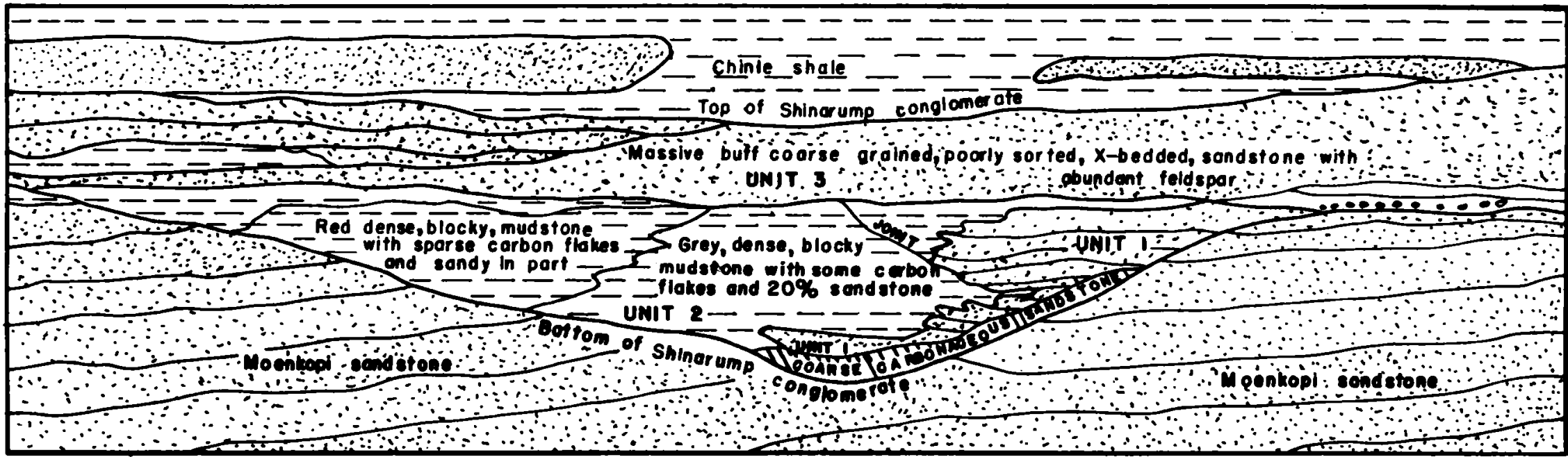

Explatiation

- sanostowe

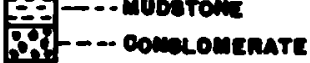

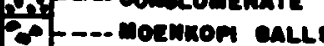

MiV-- one

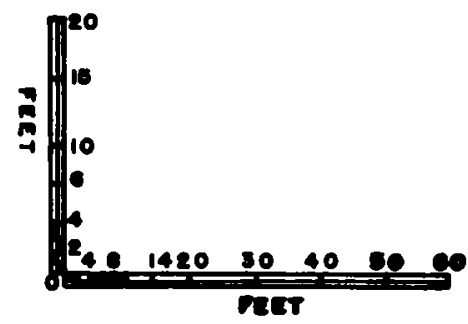

Figure 4. Cross section of Sunrise chamel.

White Conyon, Utah 


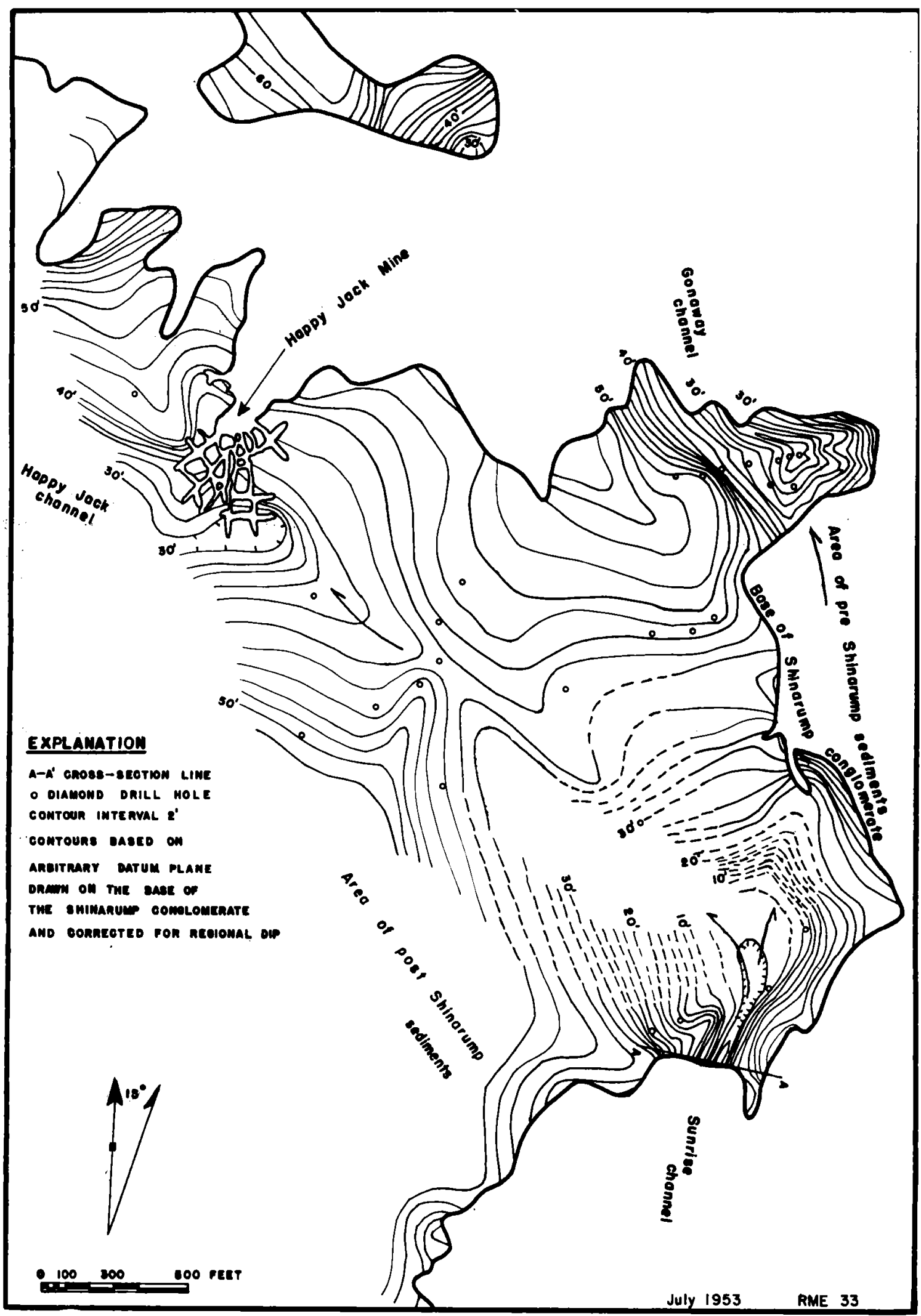

Figure 5. Channel structure contour map of Happy Jock mine and vicinity, White Canyon, Utah 


$$
\begin{aligned}
& \text { Onit } 2 \text { (middle unit), Mudstone, usually gray, commonly } \\
& \text { red; structureless, contajns some fine to coarse } \\
& \text { sand grains; has small carbonized fragments; not } \\
& \text { present outside the channel; slope-forming-- - } \\
& \text { This unit, is not ore-bearing, except when near } \\
& \text { the surface. }
\end{aligned}
$$

Unit 1 (basal unit), Sandstone, white weathers to buffs quartzose, coarse-gra ined to conglomeratic, poorly sorted, contains Moenkopl shale and sandstone fragments; friable, graine angular, clay cement, contains organic matter uch as small twigs and ferms; predominantly quartz pebbles; few chert, quartzite and jasperoid pebbles, contains microcline fragments up to 1 inch in diameter; some chert pebbles contain fossil (crynoids and corals ?); not located outside channel; slope-forming - . - . . . . . - . 5.0 This is the orembearing unit. 


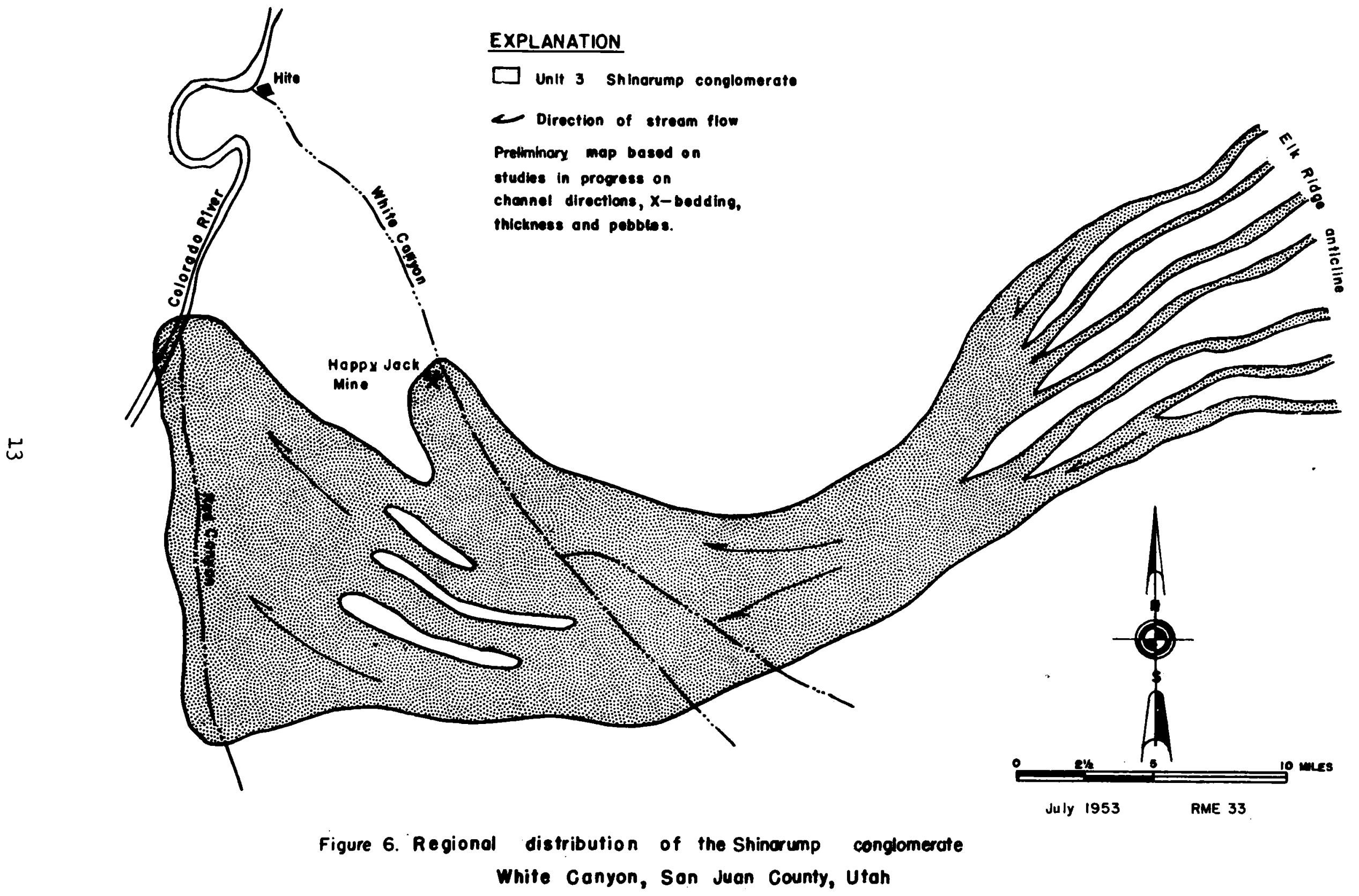


The Happy Jack deposit is located on the northwest "pinch-out" of the fan. The control that this feature may have on ore deposition 1s discussed under intra-channel ore controls.

\section{Beomorphology and Climatic Change}

A sharp change in strean drainage and clinate took place at the ond of loonkopl time.

In Incised cross-gection testifies to the youth of Shinarump otreans, and Moenkopl sandstone pebbles are an Indication of an indurated Moenkopl formation. Scour and f1Il type sedinente a ro within the chame1s. After the channelo were filled, the otreams atgrated within the inter-channel areas and deposited unit Ho. 3 (P1ge. 4 \& 6). The moandering otreans which deposited these sedinents fllled broad erosional ralloys and reached a late stage of turity. As these streams reached old age, they deposited the shales of the orerlying "DN-nomber of the Chinle formation.

Vegetal remains aro extremely rare in the red Woenkopi formation; whereas in the varlegated Chinle formation, carbonized plants, large alicifled trees, fresh water pelecypods and Iriassie vertebrates are abundant. Thlo may indicate that conditions were more suitablo for burial daring the Chinle time. A better explanation may be that a climatic change from $\mathrm{dry}$ to molat took place after Hoenkopl tine.

Both the sharp gecmorphological and posstblo clinatio changes indicate a period of diastrophlem between the koonkopl and Chinle format1ons. in angular unoonformity betwoen the two formatione noar cartio Valles, Oteh, oast of White Cenjon, beare this out.

\section{Mintarouroct}

The seneral charaoter of the ore 18 an intergrowth of uranintte

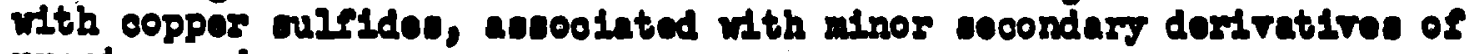
urantun and ooppor.

Orentnite 10 the primary ore minoral of uranium in the lappy Jaok doposit. Ito oharecteriet10 ocourronoe is as ropleoonont of rood and ac ocment of quarts grains. Dooomposition produote, the hydrated oulfates of uraniun, are ocmon at the outorop of the oremprison and on the wallo of the mino. The most oomon are johenntte, stppotbe, and uranop1l1te.

The prinary ore minerale of ooppor are the oulfides Chaloopyetto, ohalooolto, and borratto. These, Ilke uranint te, roplaos foost1 wood and ocment the and cratno. Seoondary ooppor minorale inolude antlort to, oovellite, broohant1te, ohaloanthito, asurite, and malaohsto. Cronor's ompliation of 1952, Givon hore a tablo 1,1 a complote liot of atnorald at the Happy Jaok mino.

$$
\text { - } 14-
$$


TABLE 1. - List of minerals from the Happy Jack mine as reported by John Gruner, et al, 1952

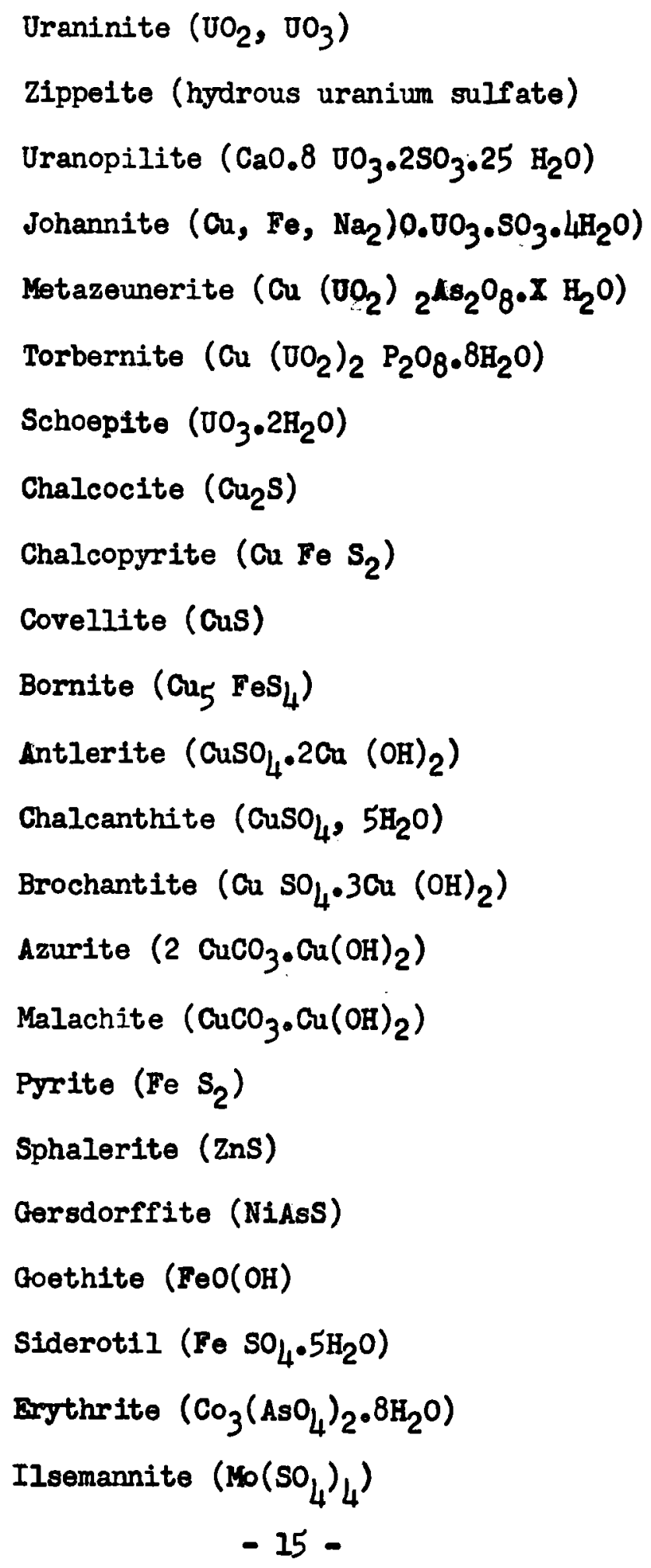


TABIE 1. - List of minerals from the Happy Jack mine (cont'd)

\author{
Barite $\left(\mathrm{BaSO}_{4}\right)$ \\ Gypsum $\left(\mathrm{CuSO}_{4}\right)$ \\ Jarosite $\left(\mathrm{K}_{2} \mathrm{Fe}_{6}\left(\mathrm{OH}_{2}\left(\mathrm{SO}_{4}\right)_{4}\right)\right.$ \\ Oyanotrichite $\left(4 \mathrm{CuO}, \mathrm{Al}_{2} \mathrm{O}_{3} \cdot \mathrm{SO}_{3} \cdot 8 \mathrm{H}_{2} \mathrm{O}\right)$
}

Sulfur (s)

$\left.(\mathrm{Co}, \mathrm{Fe}) \mathrm{SO}_{4} \cdot 4 \mathrm{H}_{2} \mathrm{O}\right)$ not described befor

$\left(\mathrm{Mg} \mathrm{SO} \mathrm{S}_{4} \cdot 6 \mathrm{H}_{2} \mathrm{O}\right)$ not described before

The ore textures of the Happy Jack deposit are of two types: (I) roplacement and (2) exsolution. The following discussion is based on a study of 30 polished surfaces and 6 thin sections.

\title{
Replacement Textures
}

\section{Organic Matter}

The most common and obvious replacement texture within the deposit is that of uraninite and chalcopyrite replacing wood cell structure (pl. I-A). Uraninite usually replaces the cell walis and chalcopyrite occupies the central portion of the cell. The reverse situation, that of uraninite in the center and chalcopyrite in the walls of the cell, is not common. The cell border cantact of uraninite and chalcopyrite is severly etched, but due to the primary structure of the wood, it is not possible to judge the time relationship between the two minerals.

Uraninite, in the absence of chalcopyrite, completely replaces the cell structure. Where this occurs the cell form is not as easily identifled.

Bornite also replaces organic matter (pI. I-B). Here it is show in two forms: (1) in replacement of cells, (2) in complete replacement of sandstone or complete replacement of wood without the pseudomorphic texture of wood.

Pyrite, chalcopyrite, and chalcocite have formed crystailine haloes of dipyramid form within the cell (pl. II-A). The extreme case is the following sequence in dipyramid form within the cell structure: first chalcopyrite surrounded by chalcocite, then pyrite, chrlcocite again and finally chalcopyrite. Chalcopyrite was formed first with each succeeding $r$ ing formed later. 


\section{Chalcopyrite Ifter Pyrite}

The complete roplacement of pyrite by chalcopyrite is common throughout the deposit (pl. II-B). The rellc structure is always a cublc pseudomorph.

Replacement of Quartz and Microcline

Quartz and microcline were readily etched by the ore minerals (pl. III, $A$ and B). It is not 11 kely that sone previous mineral etched the quartz, as quartz is not replaced where it is not in contact with the ore minerals. Microcline is replaced predominently along cleavage planes, but is not so susceptible to replacement as quartz.

Quartz overgrowths on quartz grains are common in the Shinarump conglomerate in the white Canyon area. These secondary overgrowths in specimens from the Happy Jask mine have been locally replaced by uraninite and the copper sulf1des (pl. IV-A). Btching of the secondary overgrowth is usualiy no more intense than that of the original quartz grain.

Replacement of the Clay Coment

The clay cement is replaced more completely than quartz, though not as extensively as organic matter ( $P I . I V-1)$. The adhesion betwoen the replaced clay coment and the quartz is relatively strong-adequate for thin or pollohed sections.

Irregular Border of Urantnite and the Copper Sulfides

The contact between uraninite and chalcocite, chalcopyrite and covellite is always irregular (plo, $\left.7-\Lambda_{4}\right)$. This intergrowth structure does not exist between uraninite and bornite, since chalcocite, chalcopyrite or covellite is always between the two minerals. Corellite also forms alteration or reaction rims betwoen bornite and uraninite (pl. $\nabla-A$ ). This ocourrence has also been reported by Rosenzweig and Gruner (1952). 9/

\section{Replacement in Fractures}

Oraninite has not been observed within fractures oxcept as replacement of probable shrinkage cracks in chalcopyrite (pl. V-B). Chaloopyrite very rarely replaces cracks in quartz graine (pl. VI-A) and seldom replaces fractures in mudstone and well cemented sandot one ( $p l$. VI-B).

Corellite replaces fractures in chalcoprrite, bornite, chalcocite and uraninite (pl. $\nabla I I-\Lambda)$.

$$
-17-
$$


Exsolution.

Chalcopyrite and bornite, where found together, are always in a grating pattern, bornite being the included mineral (pl. VII-A). This is apparently an exsolution texture, as described by Schwartz (1931), 10/ Edwards (1947), 11 / and Bastin (1950) 12/. The texture has the Following exsolution features: (1) chalcopyrite blade-like inclusions with no enlargement where the blades cross or join, (2) the boundaries of the inclusions are sharp, (3) bornite, the included mineral, is absent outside the intergrowths and occurs as disconnected units inside the intergrowth area.

Schwartz induced this texture in chalcopyrite-bornite ore from Globe, Arizona, by artificial heating and quenching at a minimum temperature of $475^{\circ}$ C. $10 /$ The significance of this temperature is uncertain as this was primarily a heating experiment. Pressure and the chemistry of the Happy Jack ore solutions may well have had a temperature lowering effect for the precipitation of uranium oxide.

Time Relationship Between Minerals

Due to the intergrowth of minerals, the replacement and the exsolution relationships, it is apparent that there is no orderly sequence of mineralization for the ore minerals.

Certainly the ore minerals are later than the quartz cement and quartz overgrowths, and covellite is later than any of the ore minerals. There is a suggestion that uraninite may be later than chalcopyrite, bornite, and chalcocite; as there are some cross-cutting relationships and uraninite in many cases encloses chalcopyrite.

The lack of a clear time sequence of mineral growth suggests a simultaneous deposition of the ore minerals.

\section{Alteration}

Alteration is not present in the Happy Jack deposit except as local bleaching of the red sediments to green. The lack of argillization and sericitization of the feldspars is conspicuous along with the absence of calcium carbonate and silicification (excluding secondary quartz growth). The red coloration which is common to hydrothermal uraninite deposits elsewhere in North America (Kerr, 1950) is lacking. 13/ This lack of alteration points to deposition of the minerals from a low temperature solution. It is evident, however, that the host rock consisting of quartz, siliceous cement, and microcline is not susceptible to alteration even at the temperature of $475^{\circ} \mathrm{C}$. mentioned abowe in exsolution. More polish surface work may solve the high or low temperature problem. 
kll of the uranium ore in the White Canyon area is confined to Shinarunp-filled paleostream channels. Some of these channels have been traced for $15 \mathrm{miles,}$ but the ore bodies within them are not continuous. There mat be intra-channel leatures which control ore deposition and prodnce deposits such as the Happy Jack. Th1s uranitun deposit is located on the downstream edge of a large alluvial fan. It 18 beliered that the current and sedimentation pecular to this poaltion on the aliuvial fan produced intra-channel features favorable for ore deposition;

\section{Organic Katter}

In the Shinarump conglomerates, carbonaceous debris is readilj seen but is very difficult to map by quantitative methods. An examination of drift walls in the Happy Jack mine (fig. 7, DD', HH', fig. 8 , NN', PPI) reveals an abundance of carbonaceous plant debris (ferns, twigs, and logs) within the ore shoots. A small amount of lor rank coal is present. All of the sandstones associated with ore bodies have a high percentage of organic matter which is in part or completely replaced by uranium and copper sulfides. All organic material, however, is not associated with an ore body. It would be illogical to assume that the ore solutions penetrated all portions of the deposit. It is certain, however, that carbonized wood tissue, and presumably other carbonaceous fragments which are at a maximum in the ore shoots, contain the reducing agents necessary to precipitate uranium and copper. In this and other regions, concentrations of carbonaceous material have served as leads to ore.

\section{Iithologic Controls}

The Happy Jack channel deposit is unique among the other channel deposits in the White Canyon areas intertonguing of sandstone and mudstone on a large scale produced favorable traps for the deposition of ore. Scour and fill sedimentation created a large number of bedding planes which were channelways for solutions. Where conditions of inpermeability exist, as in tightly cemented sandstones and mudstones, there is no ore ( $\mathrm{fig} .8, \mathrm{QQ}^{\prime}$ ). The lithologic controls considered here are: (1) bedding planes; (2) petrological traps; (3) intra-channel scours; and (4) basal Shinarump mudstone.

Bedding Planes

Ore is distributed in large quantities along bedding planes. It takes the form of massive tabular uraninite, as much as two inches thick, and bands of disseminated uraninite, ranging in thickness from. one to twelve inches ( $\mathrm{pl}$. VIII-B). The copper sulfides form massive laminae up to 3 inches thick and also form disseminations throughout the sandstone bed. 
Specimens taken from bedding planes display some cell structure indicating that here, too, organic matter played an important role in the precipitation of ore.

Bedding plane or shocts can be traced for short distances (fig. 7, DD') I however, an attempt to correlate these planes from drill hole logs has proven unsuccessful.

Potrological trape: An lateresting and local phenomena in the Happy Jack chenpel is the presence of the high-grade ore in a porous carbonaceors sendstone shito 18 a wedge in an Impervious mastone (IIg. 8, ERI). These ore shoote appear to hawe no relationship to the present roglonal dip. This olrcumstance may bo an indsoation of morenont of ore olution under preseure that involrod elther artesian olrculation of ground rater or hypogene solutions.

Intra-ohennel voours: Scours into the Shinaramp mudstone are f1lled with a coarse carbonsceous sandstone, unit 1 , whtch in many places carries high-grado uranium mineralization (118. 7, col). It is poselbio to correlate this feature for distances through the deposit by the ald of a lence diagram (fig. 9). The porous sandston within the scour may hare acted as a pipe through the mudstone for the ore solutions.

Basal Shinarump Mudstore: The workings on the east side of the Happy Jack mine have a Ilbor of Shinarum madstone overlatin by andstones on the west side of the mine, the Shinerump: andotons rests direot $1 \mathrm{y}$ on the Moonkopl formetion (11g. 10). The rich ore ohoots are confl ned to the oand otom which reate on Shinarump mudstone, whereas the sandetone which rests direotly on the Hoenkopi 10 leokling in high crede ore. Tro explanats ons are offered for this phonomanon: (1) the mudetono provided an impormeablo $1100 \mathrm{r}$ for the solutions or (2) the madetono contals an abundanos of orgen10 flakes whloh during the potriflontion produoed onough uranyl roduolng gases to proolpttato tho ureatum irom the ore colutione in the ororlying oandotone.

This mudotom unst oan be traoed for cons diotmos (I1ge. 9 and 20) and a logioal prodiotion of 1te looation on be made.

Thore 1o atrong posoibility that Shinarump oandoton 2100 bnoath the midetorn eloor on the east olde of the Bappy Jaok mine (E1g. 7, orene cootion DD' in the rointty of op. 27). It 10 posalbie that more ore oxiots in this looslty undor the sloor.

\section{Ohemal Ioure}

The Happy jaok ohamel goton has Intra-ohannol "Iown" an deap

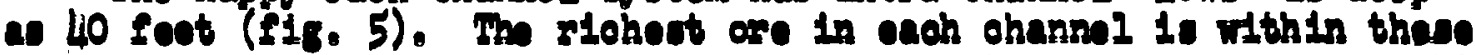
"Iow". The ore may paratot betreen the "Iow" but beoomes quite thin.


oonglomorate the bacel unit is urually abcont on the "higho". The intertonguins of these unite in the "Ioun" hes produoed favorable endinantary otruatures for the conoentration of ore. 


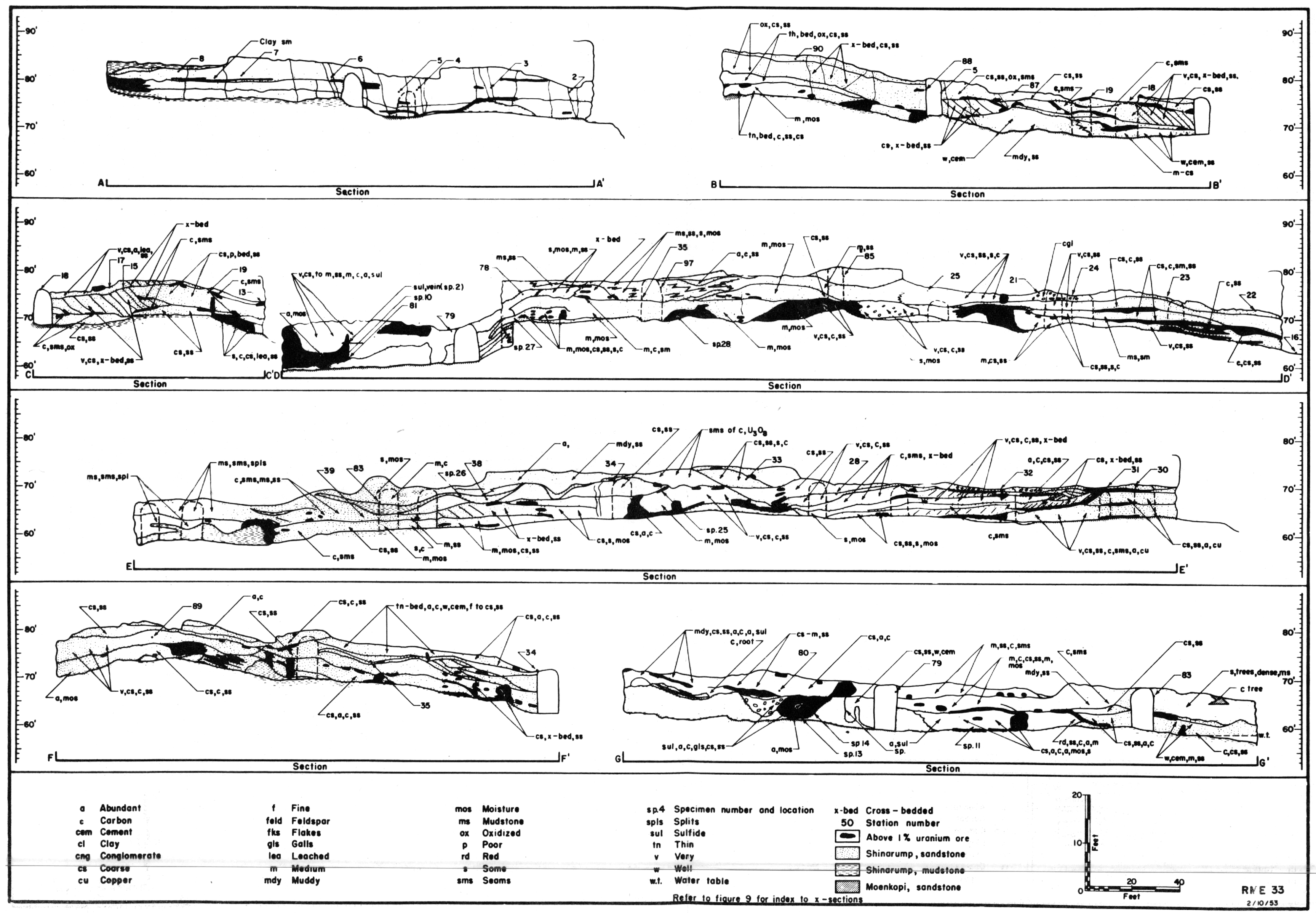

Figure 7. Cross sections $A A^{\prime}-G G^{\prime}$ of Happy Jack mine, White Canyon, Utah 


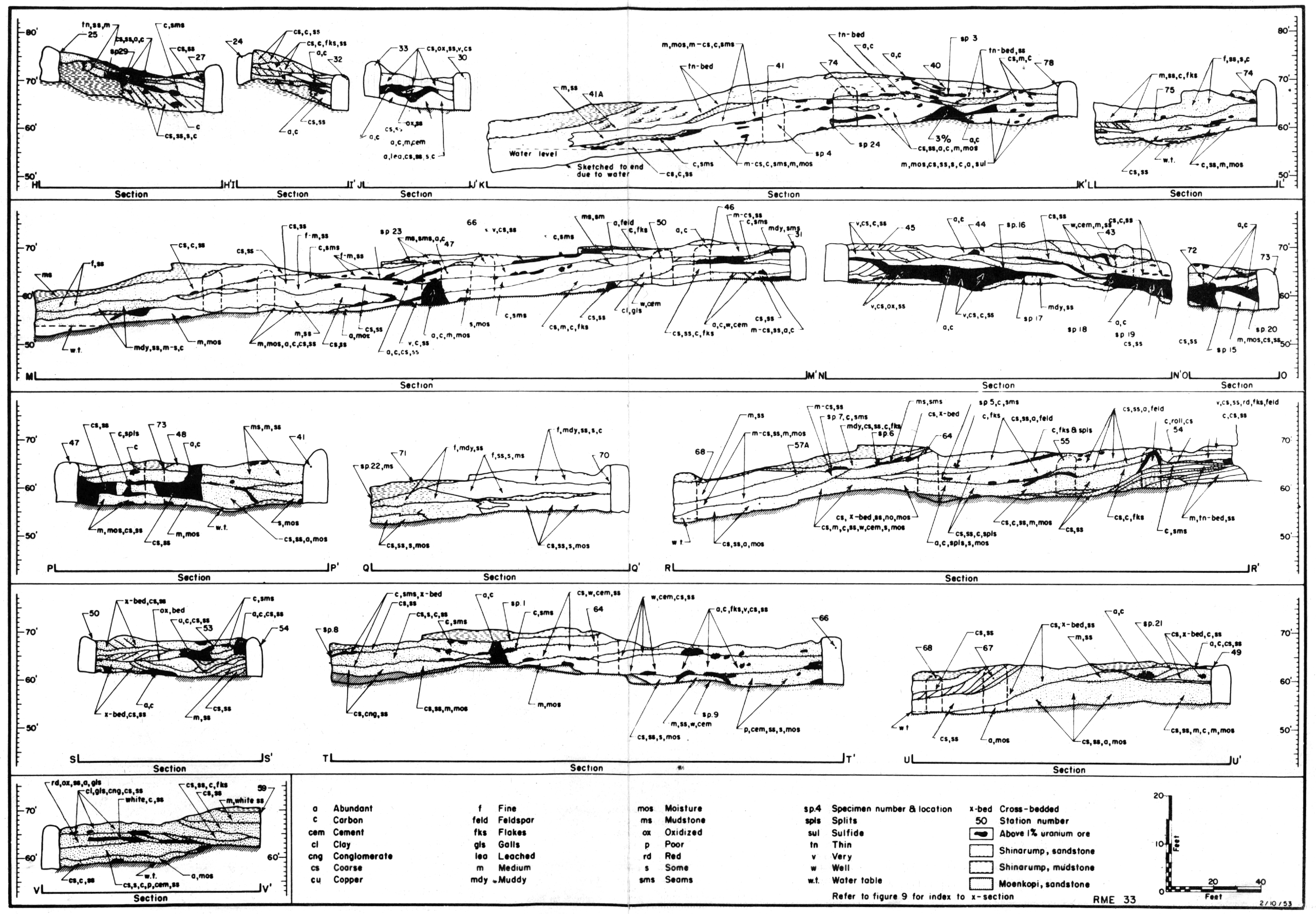

Figure 8. Cross sections $\mathrm{HH}^{\prime}-\mathrm{VW}^{\prime}$ of Hoppy Jack mine, White Canyon, Utah 


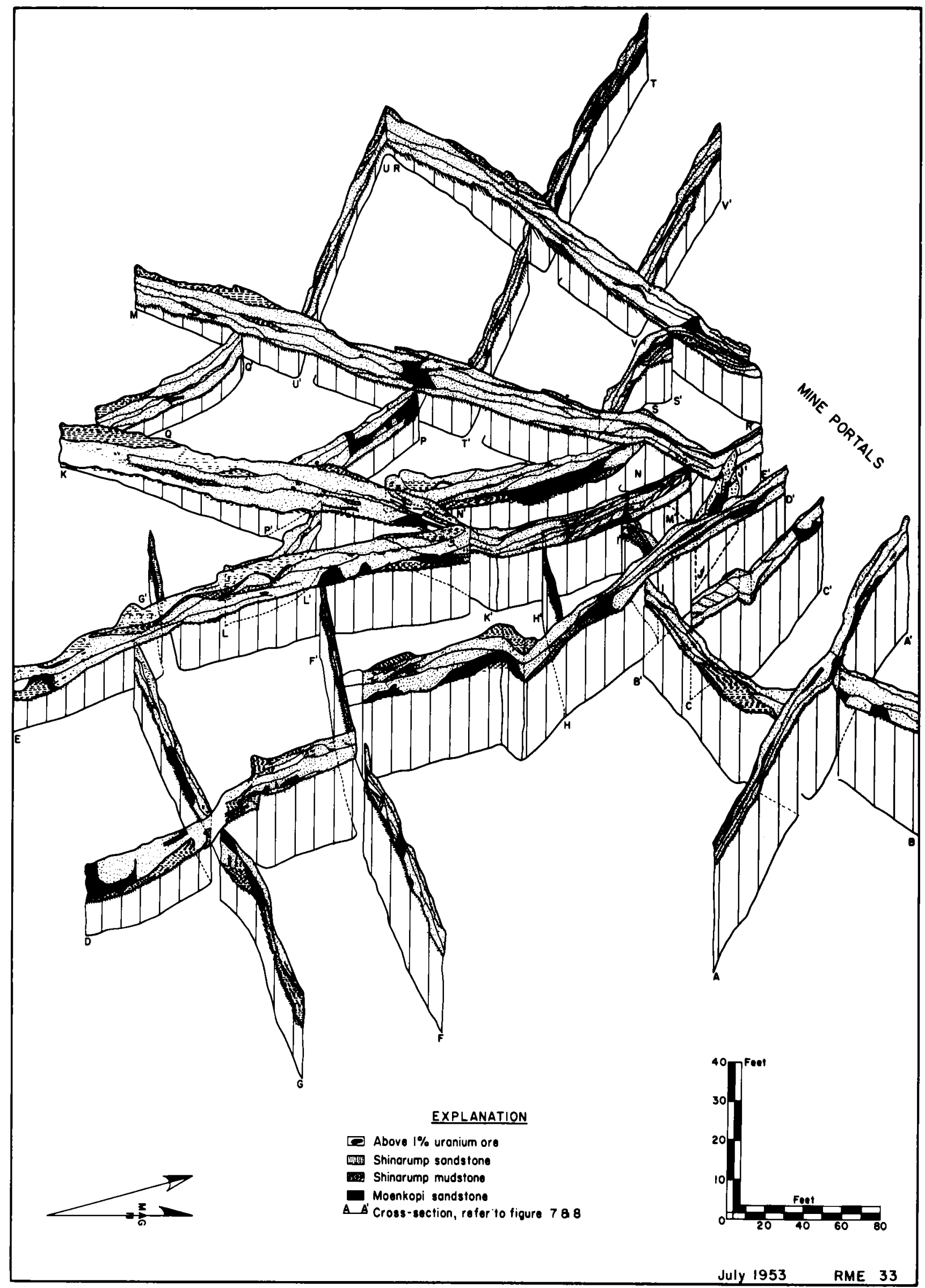

Figure 9

Fence diagram, Happy Jack mine, White Canyon, Utah 


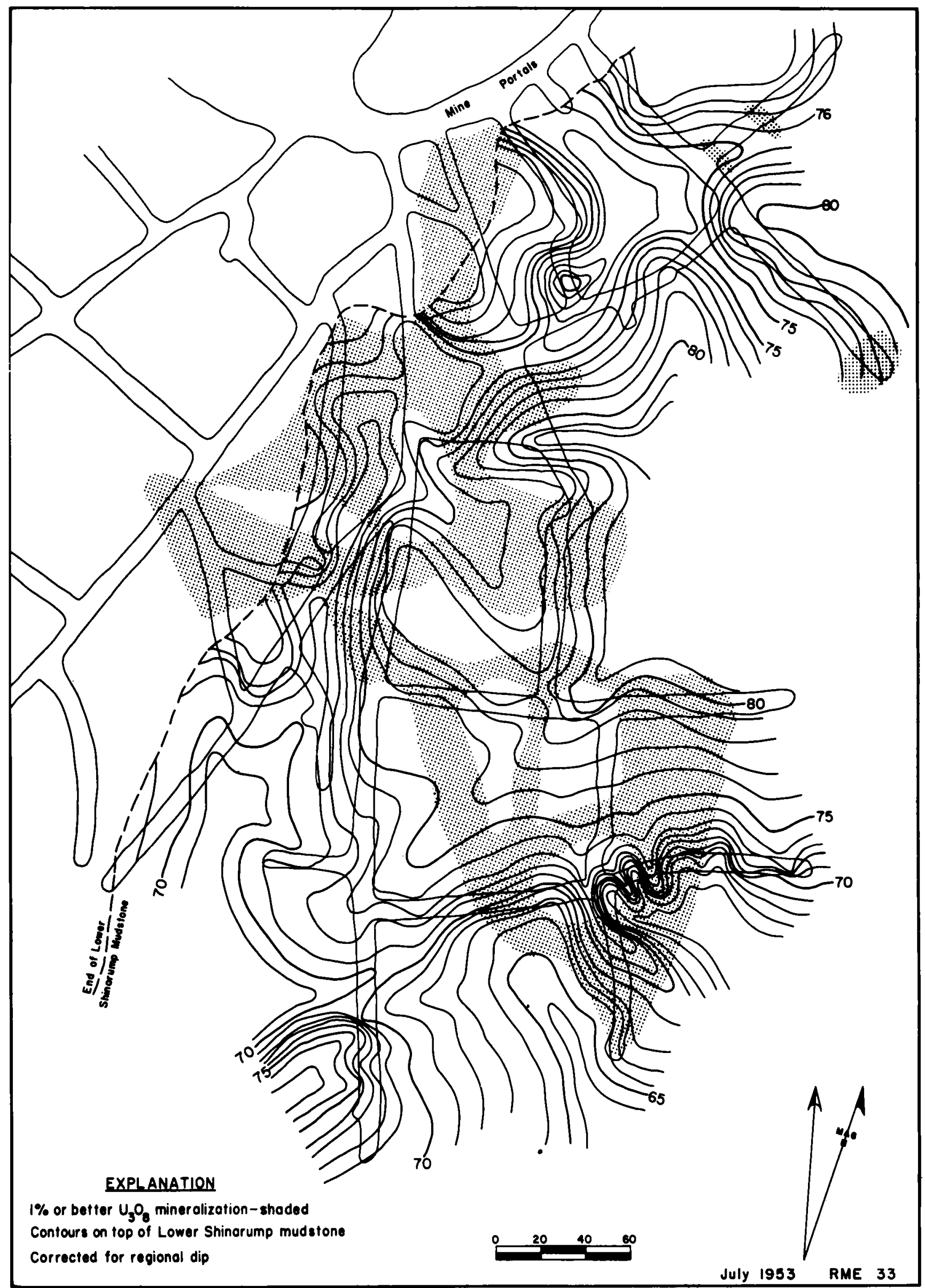

Figure 10

Lower Shinarump mudstone map, Happy Jack mine, White Canyon, Utah 


\section{Fractures}

Three types of fractures are present in the Happy Jack mine: (1) joints, (2) small faults (displacement l-foot) caused by regional tension, (3) minor faults that are the result of pene-contemporaneous compaction. There is no primary uranium mineralization associated with any of these.

Meny geologists (oral communication with Plateau geologists) believe that regional stress produced local zones of shear which fractured the quartz grains, and increased the porosity of the sandstone. This theory has no relation to facts. The quartz grains in the primary ore at Happy Jack show no uranium in fractures; they show instead an interstitial replacement of the grains and their cement. It is common in the area for the secondary minerals of uraniun, which form near the surface, to Ile along joint surfaces and even fractures within the grains ( $\mathrm{pl}$. VIII-A)。 This is to be expected where the erosion of the overburden has released the pressure allowing open spaces to form both in the sandstone units and quartz grains. Ground water dissolves the uraninite and re-precipitates it in open spaces, usually as a sulfate.

\section{CONCLUSIONS}

There are several theories on the occurrence of uranium in the Happy Jack area which have substantial proof:

1. All of the uranium ore is confined to a Shinarump stream channel.

2. The ore within the channel is largely controlled by organio matter, I1thologlo features, and channal 10ws. Kost of these controls can be mapped and with their ald favorable ore-ground may be predicted beyond the outcrop and beyond the mine headi. Ing.

3. The ore, from evidence gathered, 18 not the result of eyngenetic activity. It replaces the cement of the sandetone and the secondary growth on quartz graine.

4. Structures of tectonic origin appear to have been unimportant in the locallzing of ore bodles.

5. There is no alteration of the minerals within the deposit.

6. The Happy Jack mine is a replecement ore deposit.

Not enough evidence has been assembled in this paper to contribute any new ideas on genests of the Happy Jack ore deposit. It is clear, however, that the deposit is of epigenetic origin.

$$
-2,5=
$$




\section{REFERENCES}

1/ Gregory s H. E., The San Juan County: U. S. Geol. Survey Prof. Paper 188, 1938.

2/ Fischer, R. P., and King, R. U., Investigations of uranium deposits In White Canyon, San Juan County, Utah: U. S. Ceol. Survey Trace Elements Memorandum Report, 7-A, 1948.

3/ Suyth, S. K., The copper-uranium deposits in White Canyon, Utah: U. S. Noinic Energy Commission (unpublished report), 1949.

4/ Oranger, H. C., and Beroni, . E. P., Uranium occurrences in whito Cenyon, San Juan County; Jtah: J. S. Geol. Survey Trace Elements Memorandum Report, 7, 1950.

5 Benson, W. E., Trites, A. F., Beroni, E. P., and Feeger, J.A., Preliminary report on the White Canyon area, San Juan County, Utah: J. S. Ceol. Survey Cir. 325, 1952.

6/. Dodd, P. H., Happy Jack mine, White Canjon, Utahs U. S. Atomic Inergy Comission report, RMO-660, 1950.

If Baln, Q. W., Impressions of mineralization at the Heppy Jack mines 0. S. Atomio Inares Comalsaton momorandum, 1951.

8/ Gruner, J. W, and Gardiner, Lynn, Mineral associations in the uranium deposits of the Colorado Plateau and adjacent regions with special emphasis on those in the Shinarump formation: Annual Report to the Atomic Energy Commission, BM0-566, 1952.

9/ Rosenzweig, A., Gruner, J. W. Gardiner, Lynn, Widespread distribution and character of uraninite from the Triassic and Jurassic sediments of the Colorado Plateau: unpublished paper given at the GSA moeting, 1952.

10/ Schwartz, G. M., Intergrowths of bornite and chalcopyrite: Econ. Ceol., vol. 26, pp. 86-201, 1931.

11/ Edwards, A. B., Textures of the ore minerals and their significance, Australian Inst. Min. Metall., Melbourne, 1947.

12/ Bastin, E. S., Interpretation of ore textures: The Geol. Soc. of imer. Memoir 45, 1950

13/ Kerr, P. F., Mineralogical studies of uraninite and uraninite-bearing deposits, U. S. Atomic Energy Interim Tech. Report, 1950.

14/ Stieff, R. R。, and Stern, T. W., The identification and lead-uranium ratio ages of massive uraninite from the Shinarump conglomerate, Utah: U. S. Geol. Survey, TEMR-317, October, 1951.

15/ Miller, L. J., Investigational drilling on the Happy Jack mine area, White Canyon, Utah: U. S. Atomic Energy Comission, Report RMO-825, 1952. 


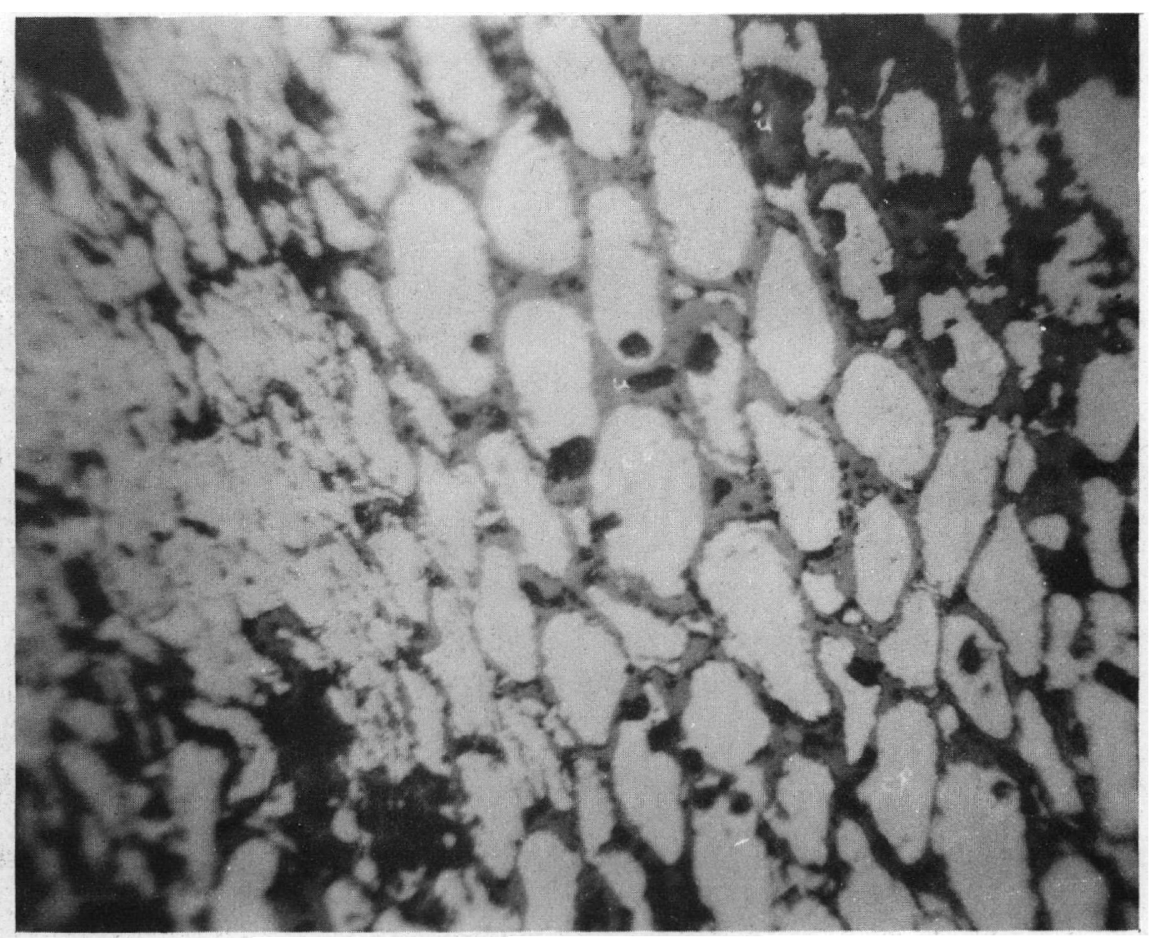

Plate I-A. Filling of wood cells by chalcopyrite. Uraninite surrounds the chalcopyrite and largely replaces the cell walls. Polished section of specimen No. 3. $400 x$

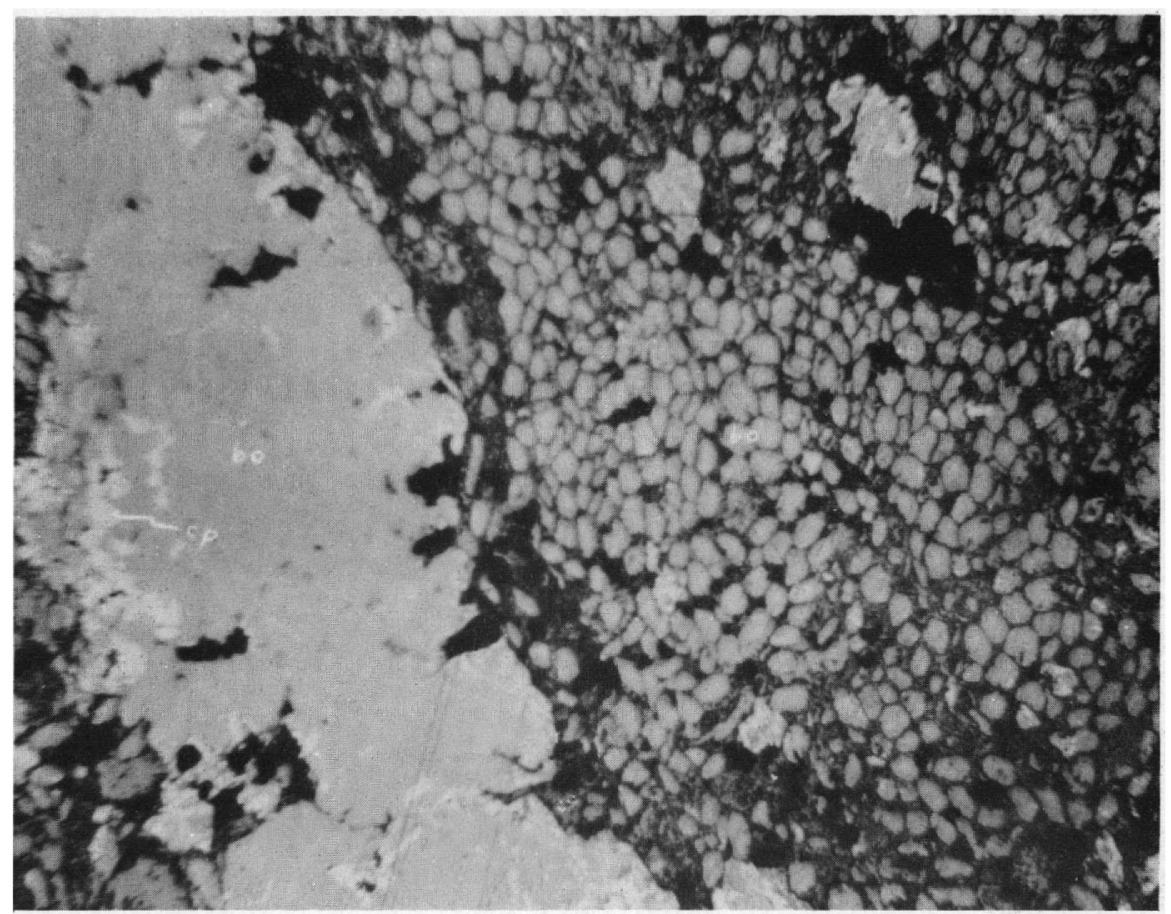

Plate I-B. Filling of wood cells by bornite. Note also massive bornite. Chalcocite replaced cell walls.

Polished section of specimen No, 19A, 100x 


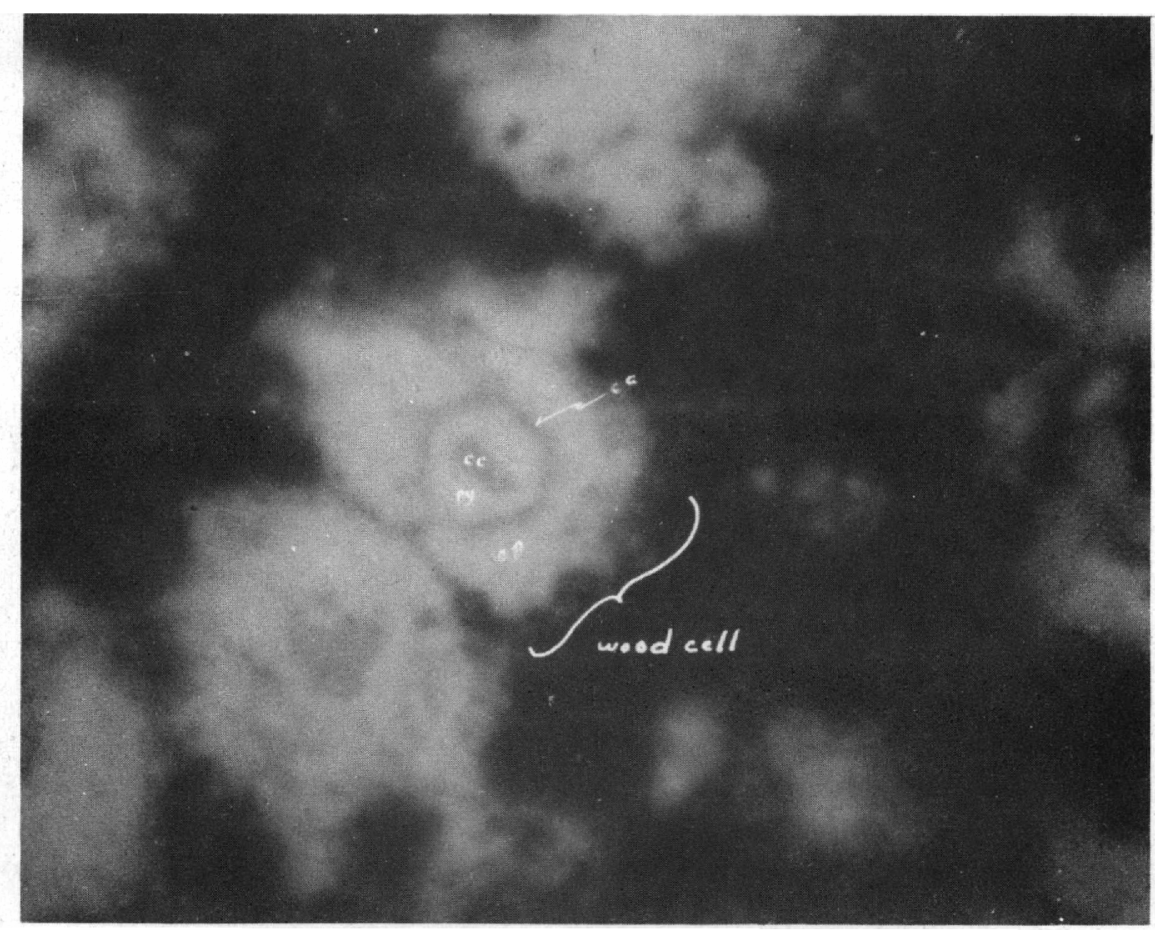

Plate II-A. Crystalline halos of chalcocite, pyrite, and chalcopyrite within a wood cell. Polished section of specimen No. 27. 1940x

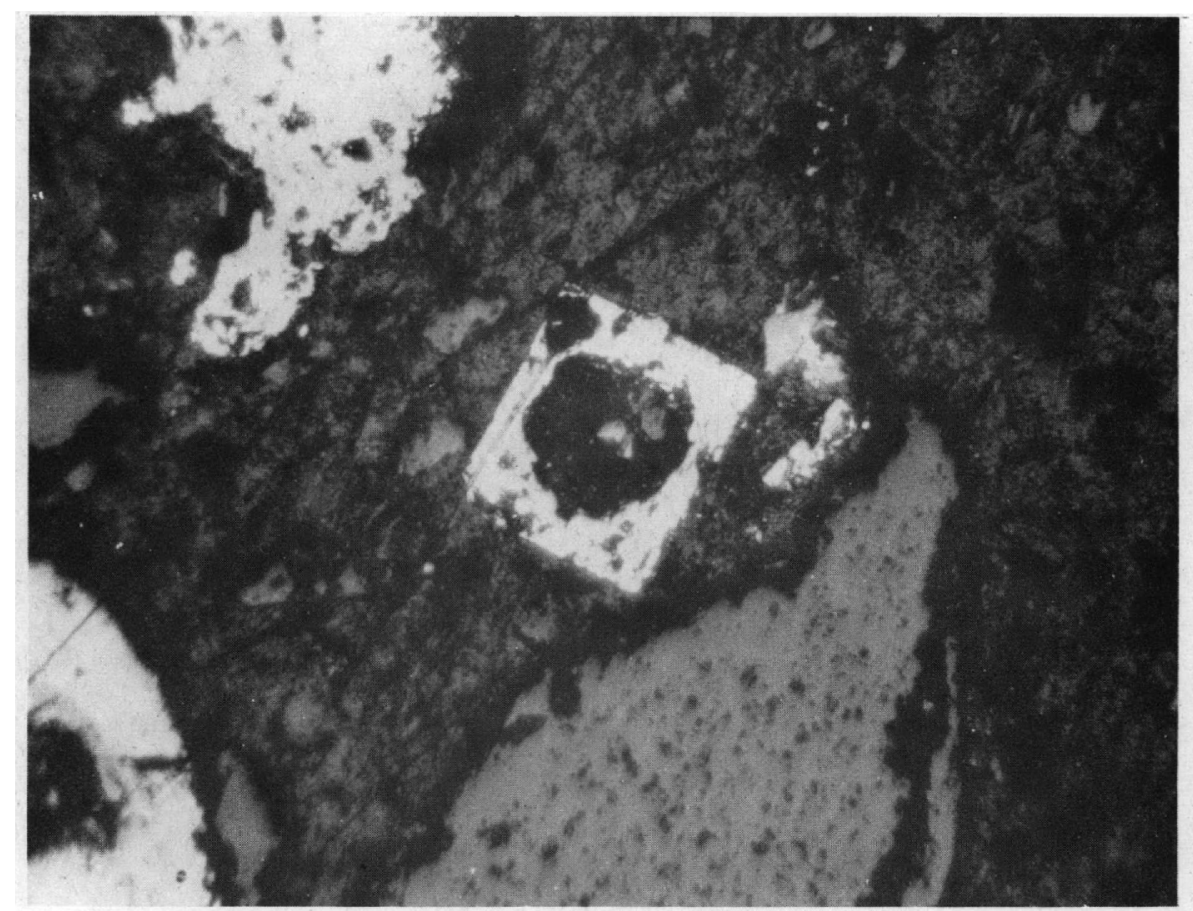

Plate II-B. Psuedomorph of chalcopyrite after pyrite. Pollished section of specimer No. 20. 100x 


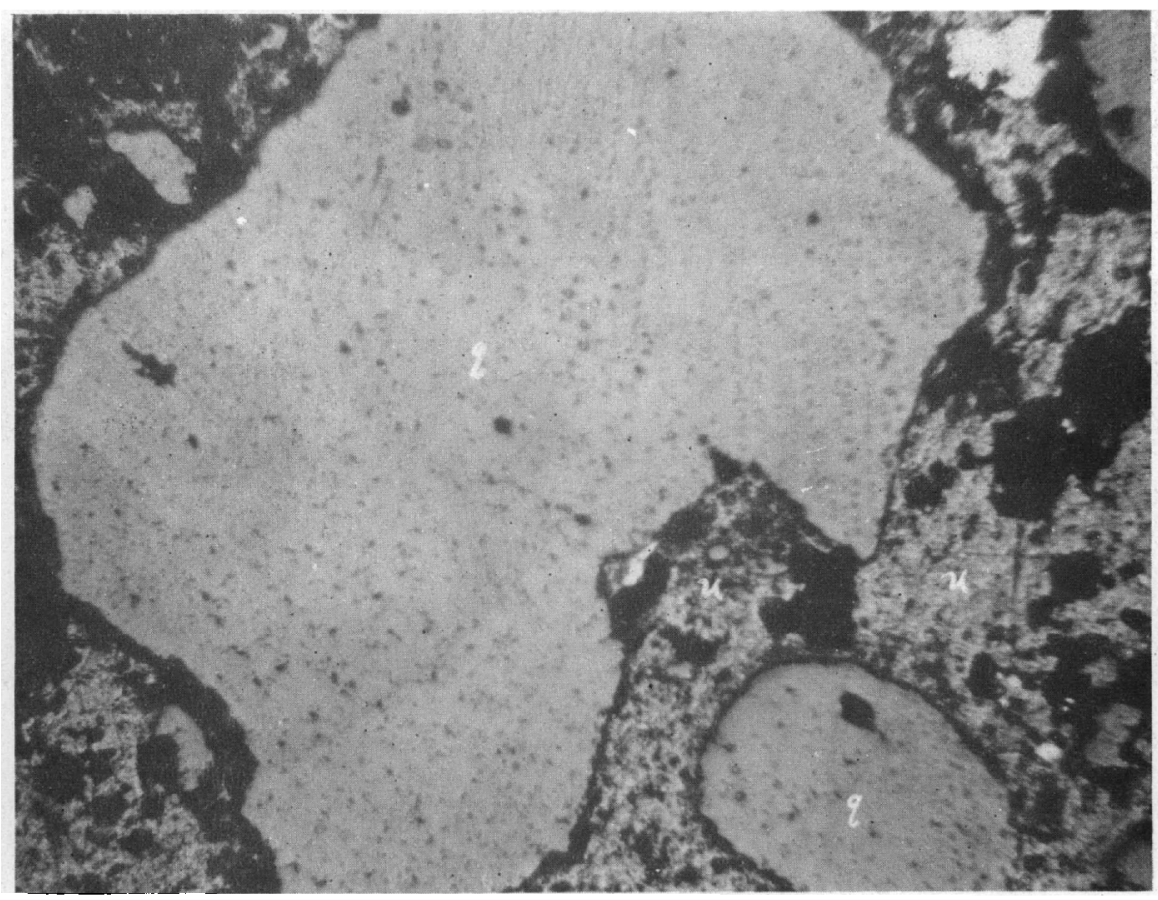

Plate III-A. Replacement of quartz by uraninite. Polished section of specimen No. 19. $100 x$

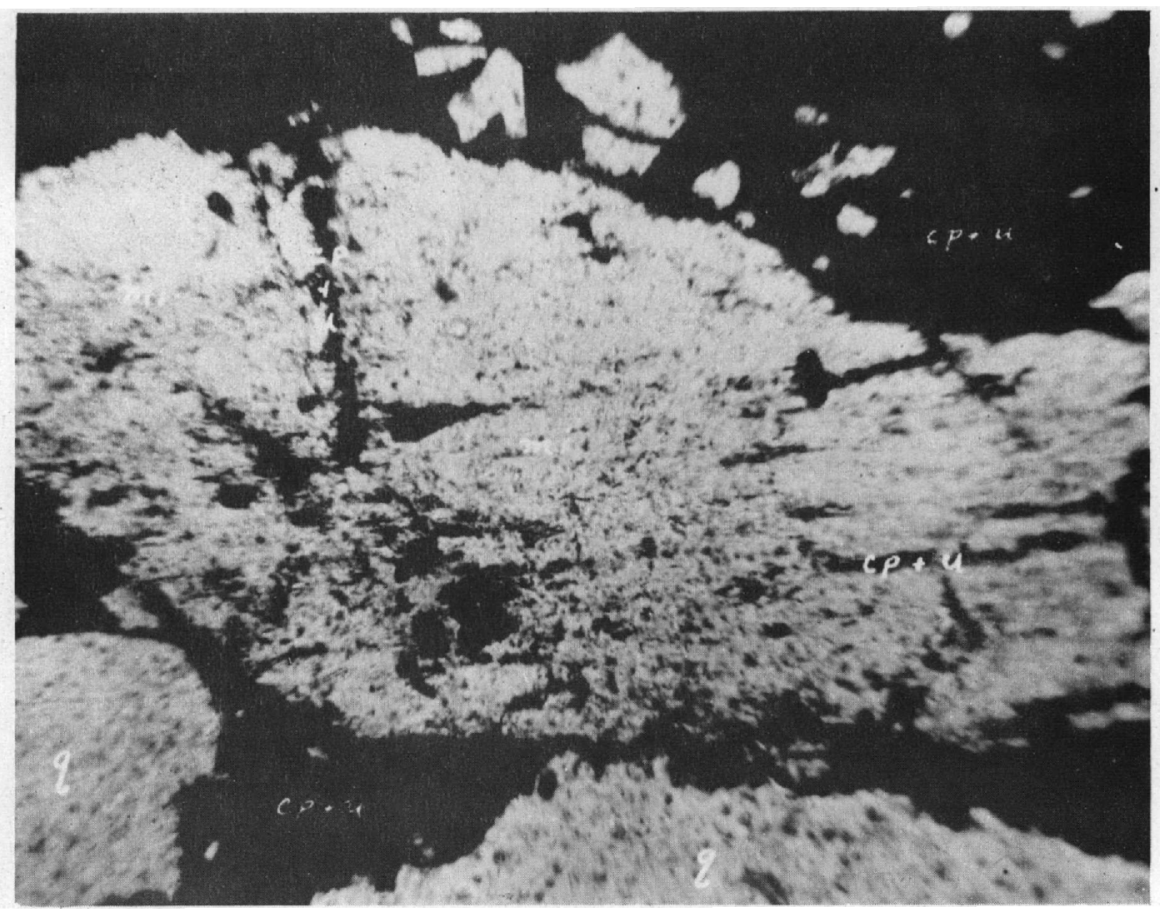

Plate III-B. Replacement of microcline along cleavage planes by chalcopyrite and uraninite. Thin section of specimen No. 3. $200 x$ 


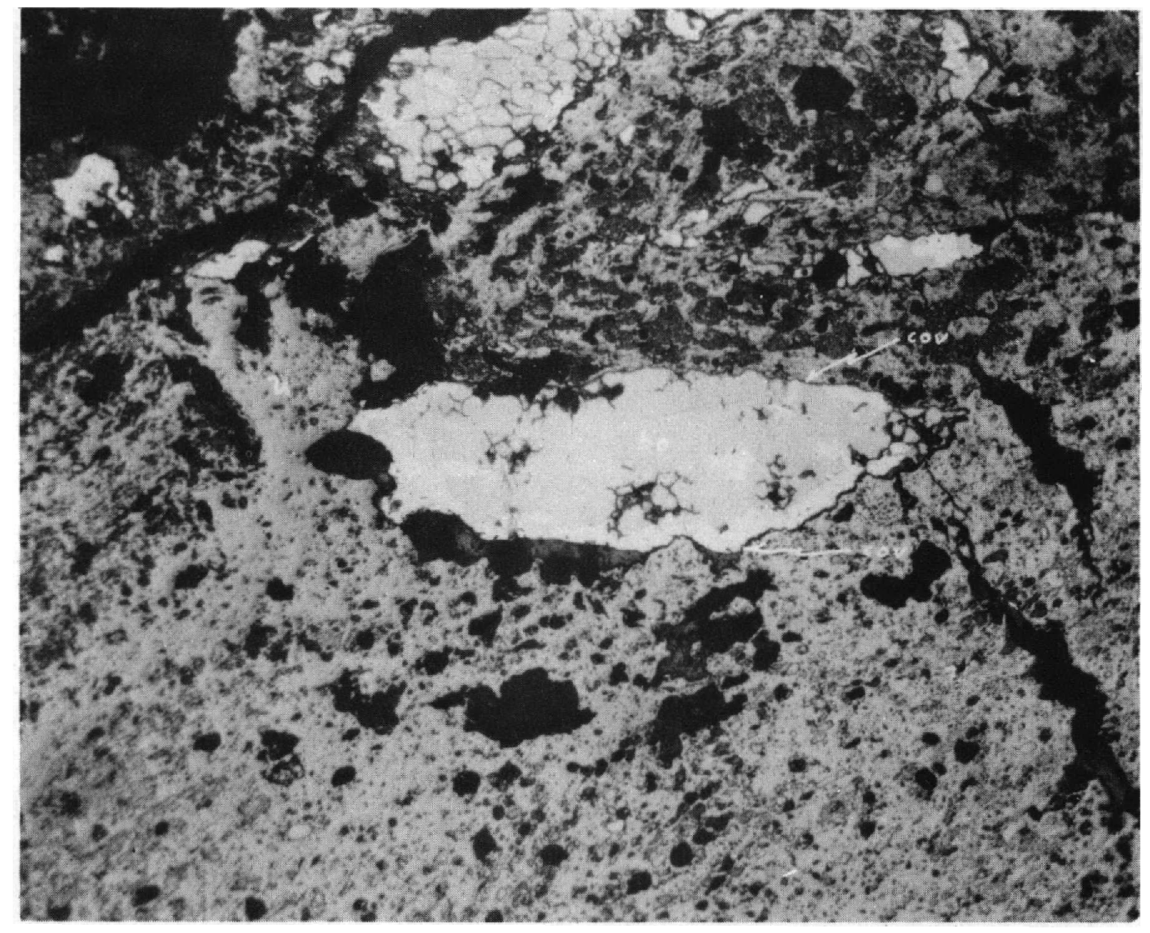

Plate IV-A. Intergrowth of uraninite and chalcopyrlte. Note dark alteration rim of corellite encircling the chalcopyrite and bornite grain. Polished section of specimen No. 18. 100x

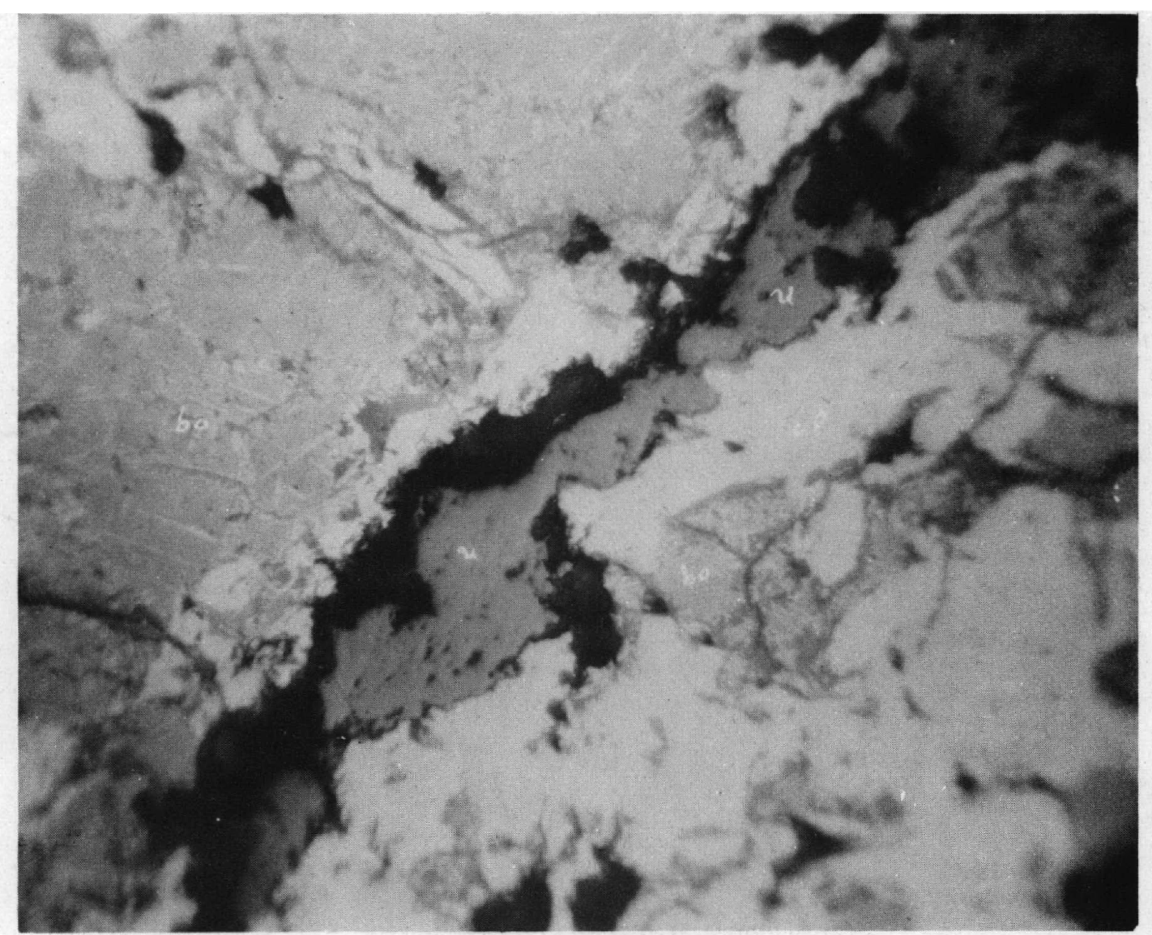

Plate IV-B. Uraninite cross cutting chalcopyrite and bornite. Note exsolution texture in bornite. Polished section of specimen No. 18 . $400 x$ 


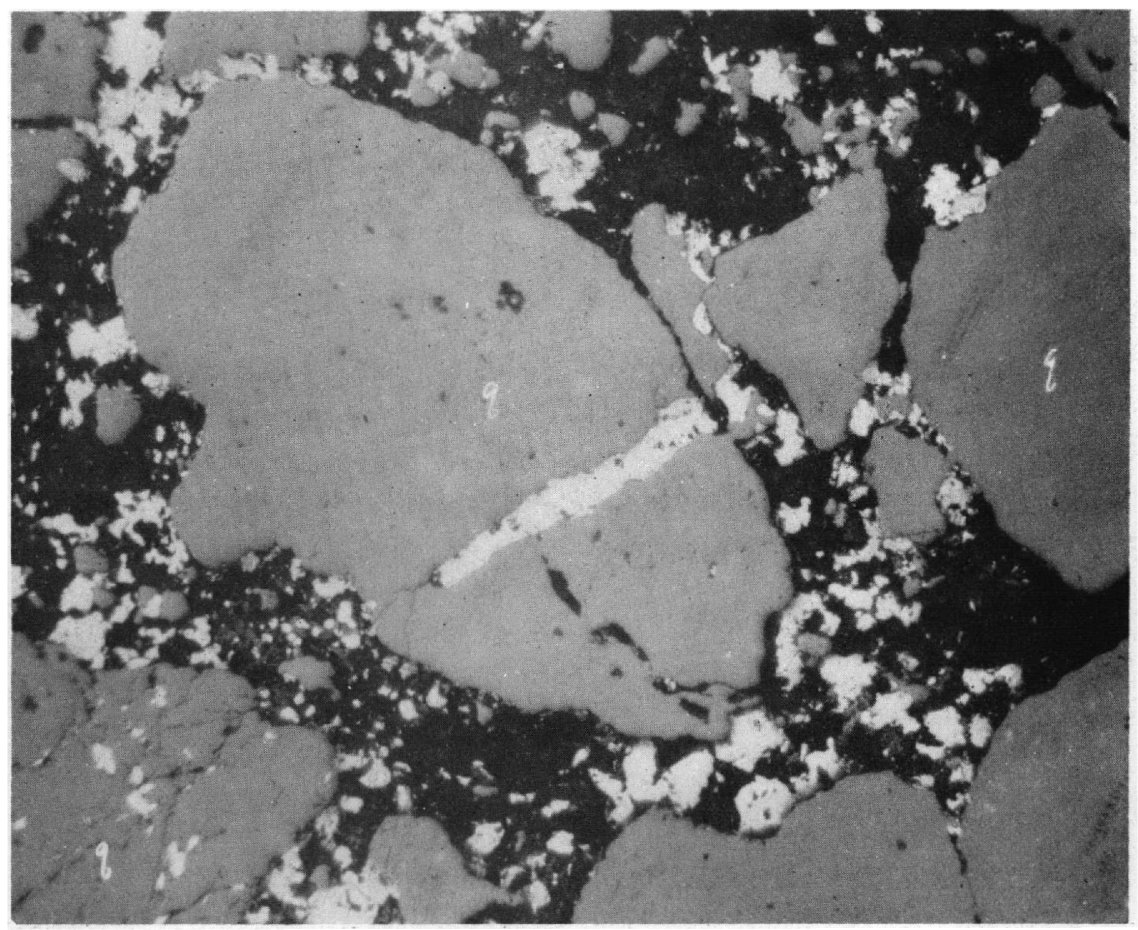

Plate V-A. Replacement of a fracture in quartz by chalcopyrite. Polished section of spec1men No. 15. 100x

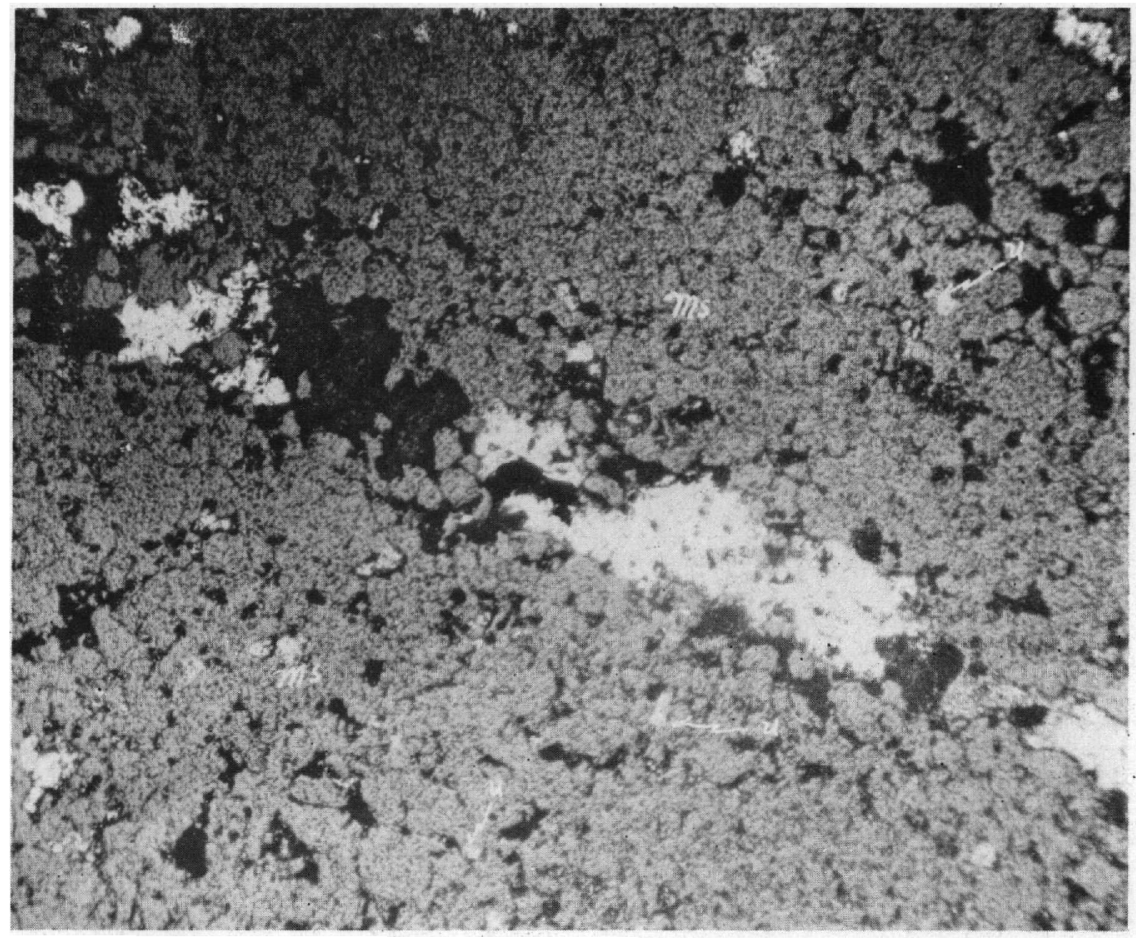

Plate V-B. Replacement of a fracture in mudstone by chalcopyrite. Note grain of uraninite outside fracture. Poliahed section of specimen No. 17. $28 x$ 




Plate VI-A. Replacement of quartz overgrowth by chalcopyrite and uraninite. Thin section of specimen No. $8.200 x$

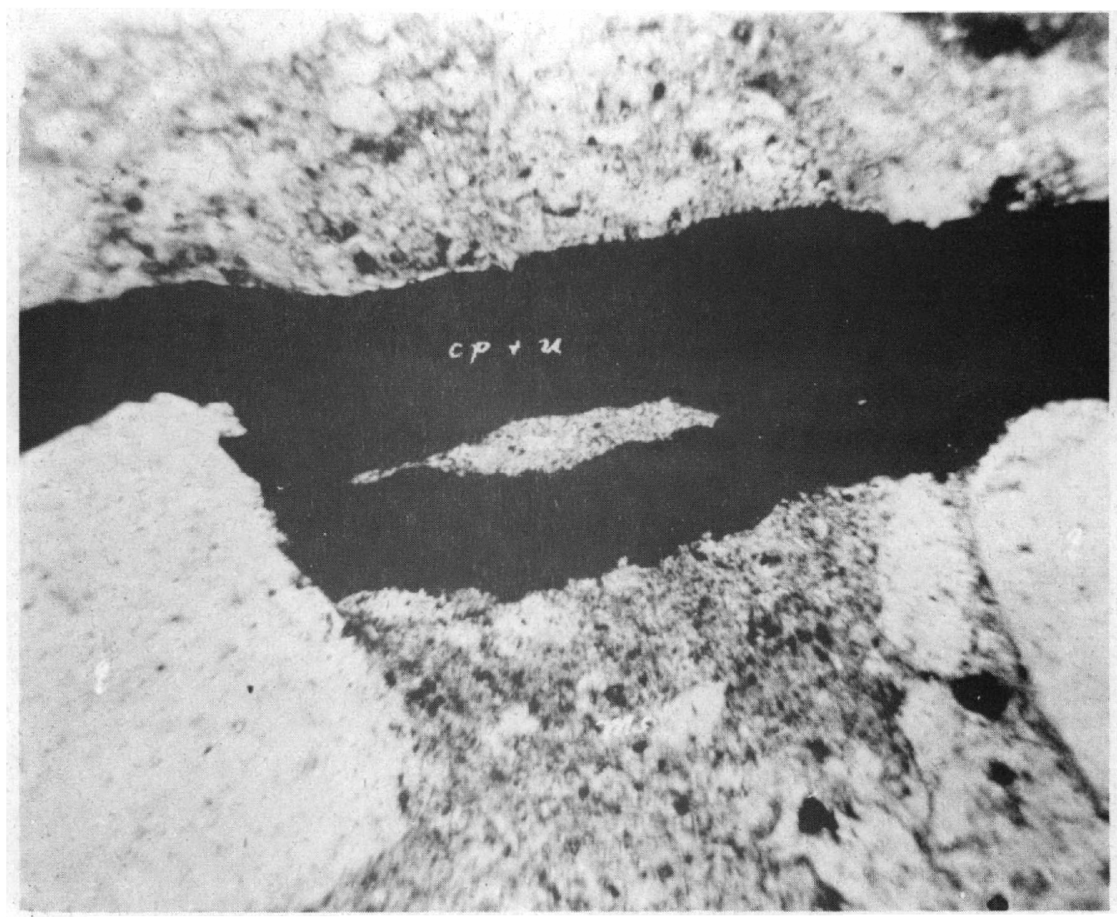

Plate VI-B. Replacement of mudstone by chalcopyrite and uraninite. Thin section of specimen No. 9. 200x 


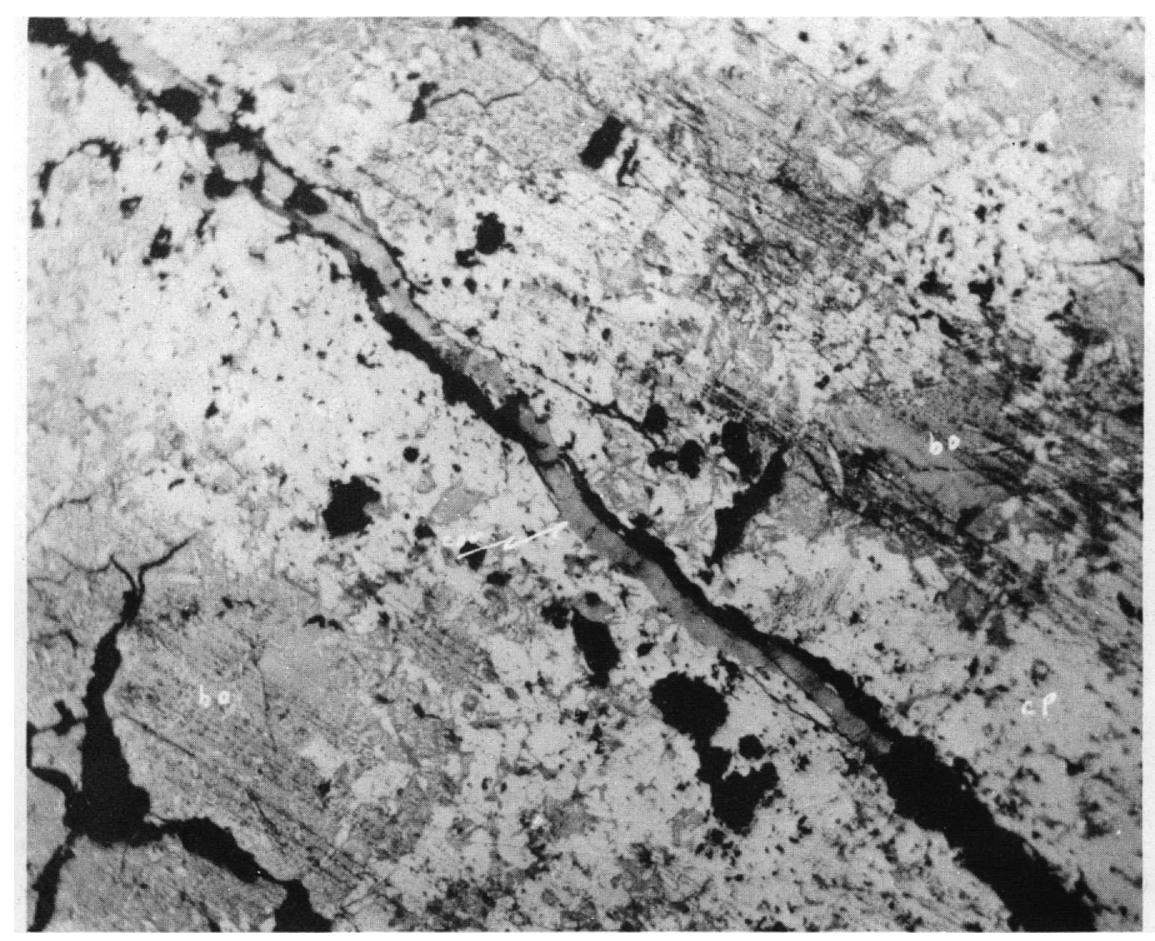

Plate VII-A. Replacement of a fracture in chalcopyrite by corellite. Polished section of specimen No. 19. 100x

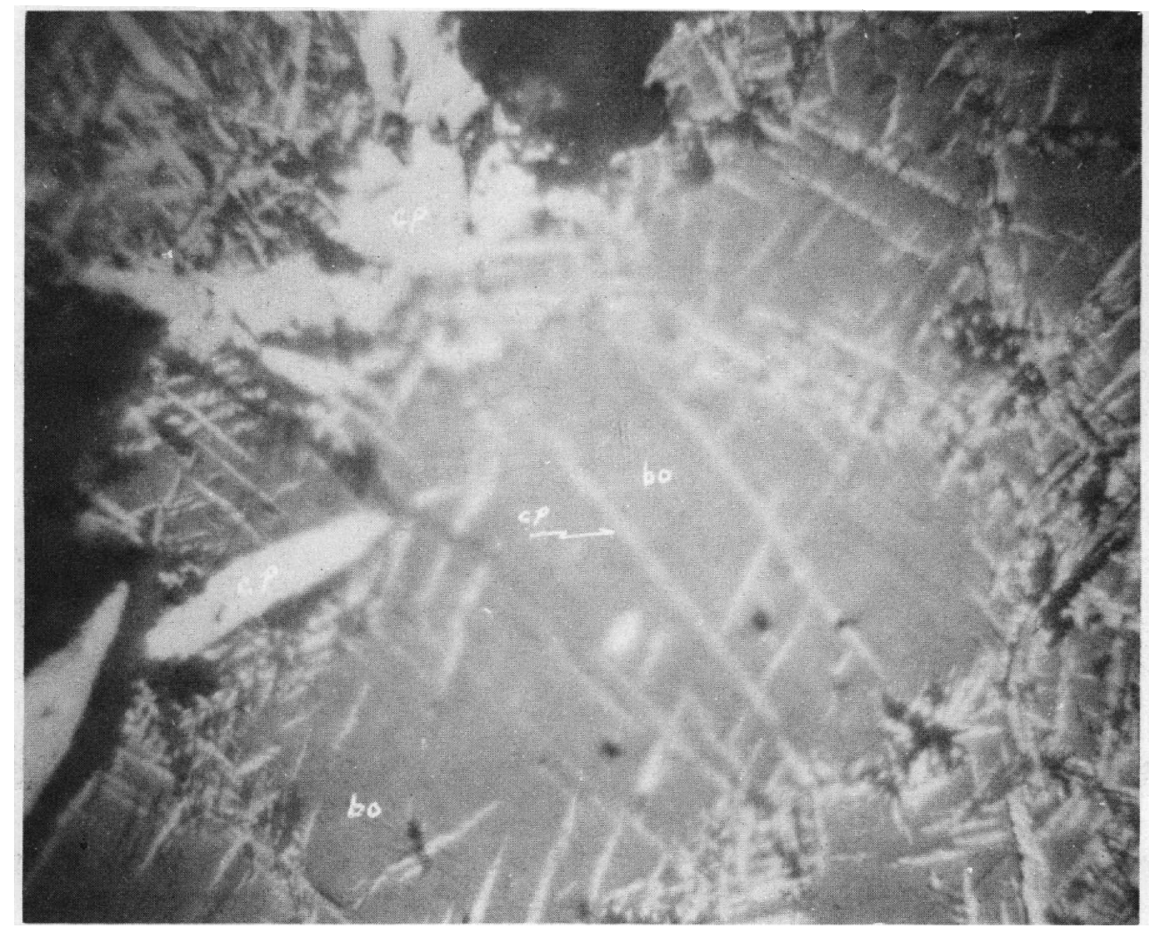

Plate VII-B. Exsolution texture of chalcopyrite and bornite. Polished section of specimen No. 18. 1940x oil immersion 


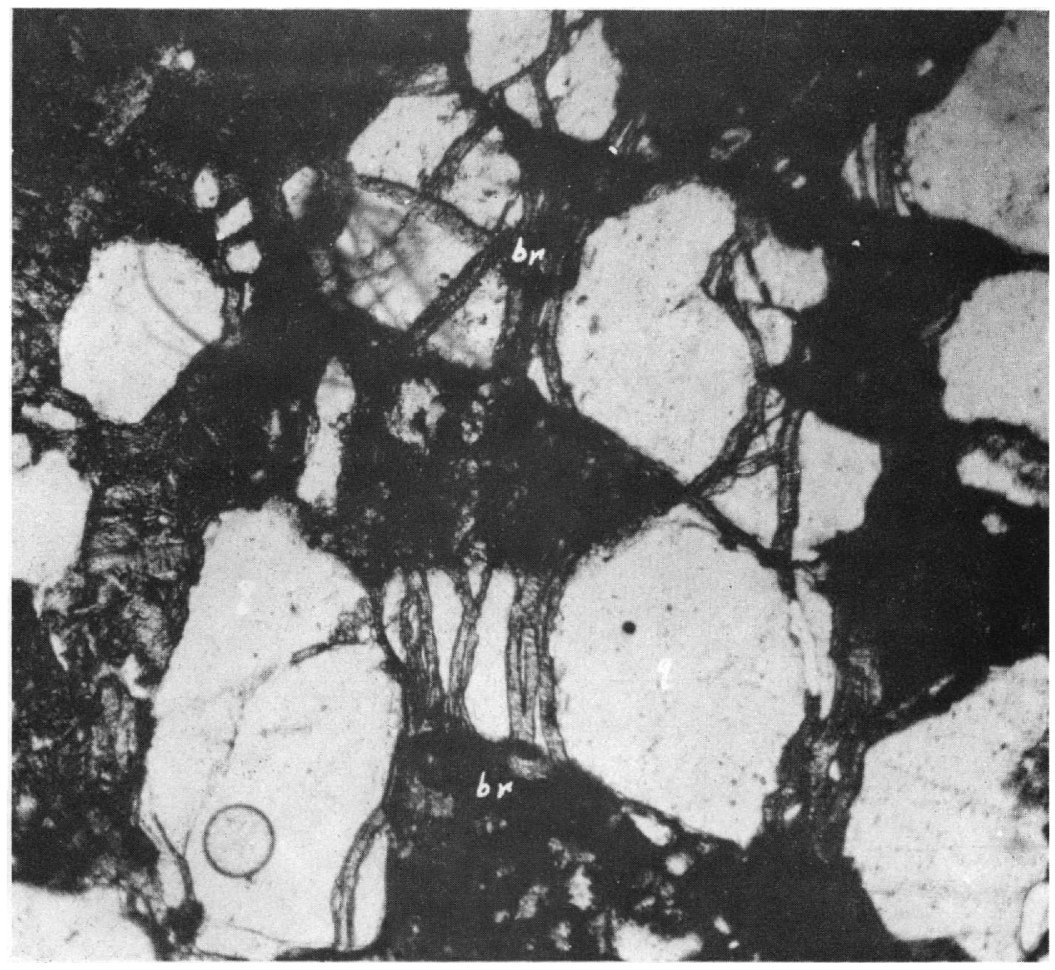

Plate VIII-A. Brochant1te whthin fractures in quartz. Thin section from Yorth Point No, 6. 100x

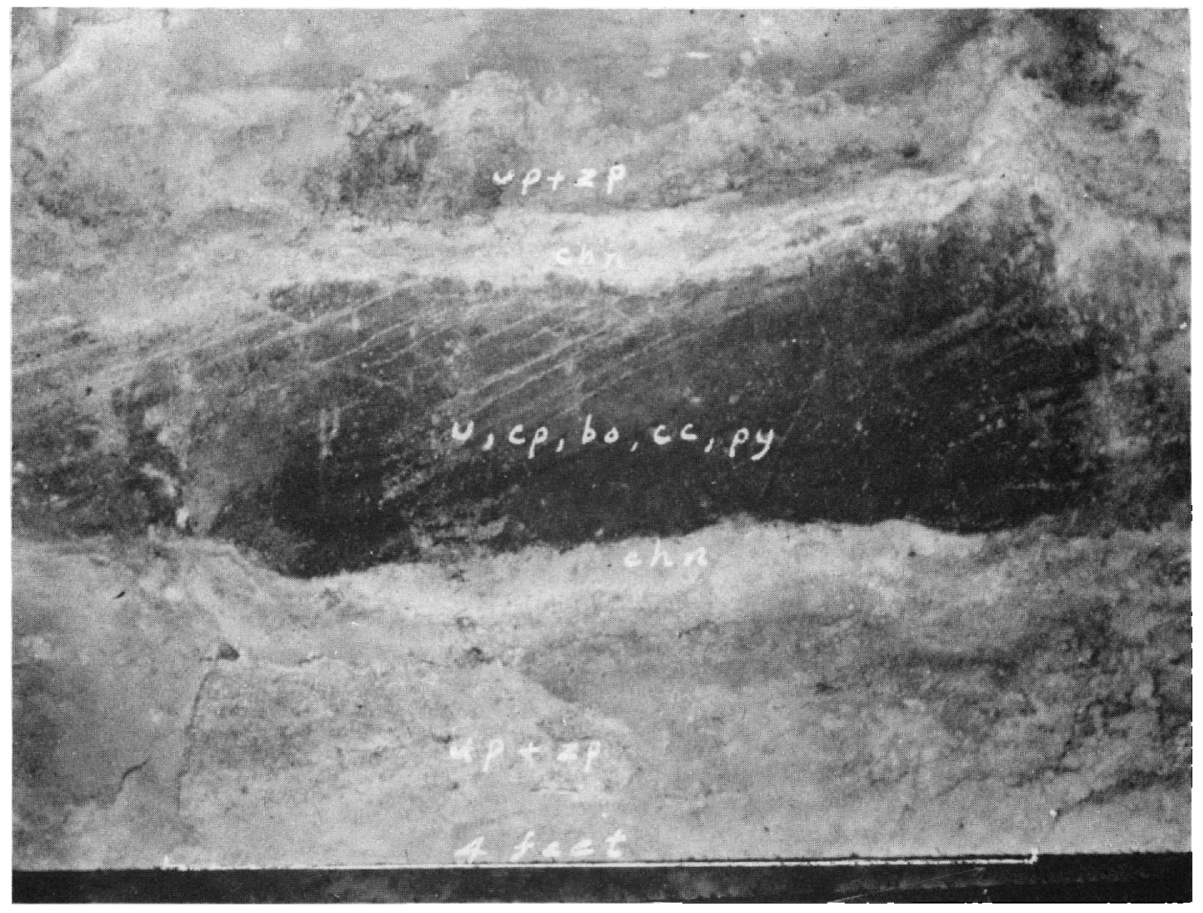

Plate VIII-B. Band of uraninite mixed with copper sulfides l-foot thick along a bedding plane. Note how ore fills cross beds.
chn = chalcanthite
up = uranopilite
ce = chalocite
u uraninite bo = bornite
cp = chalcopyrite
py a pyrite
zp $=$ zippeite 